\title{
SETTLEMENT AND SWIFT PARROTS - HISTORIC AND ONGOING HABITAT LOSS FOR A CRITICALLY ENDANGERED SPECIES (1788-2016)
}

\author{
by Debra L. Saunders and Tracey Russell \\ (with two igures and twelve plates)
}

\begin{abstract}
Saunders, D.L. \& Russell, T. 2016 (15:xii) Settlement and Swift Parrots — historic and ongoing habitat loss for a critically endangered species (1788-2016). Papers and Proceedings of the Royal Society of Tasmania 150(2): 55-73. https://doi.org/10.26749/rstpp.150.2.55 ISSN 0080-4703. Fenner School of Environment and Society, Australian National University, Canberra, ACT, 0200 Australia (DLS*). School of Life and Environmental Sciences, The University of Sydney, Sydney, NSW, 2006 Australia (TR). *Author for correspondence. Email: debbie.saunders@anu.edu.au
\end{abstract}

The Swift Parrot, Lathamus discolor White, 1790, was among the first of Australia's birds to be scientifically described and illustrated following European settlement in 1788. Within 60 years of settlement, key habitat throughout the species' range was being lost. A unique compilation of historical and recent information on Swift Parrot habitat loss demonstrates how past events have rendered this species Critically Endangered. A crucial aspect of the loss of habitat is the speed and spatial extent over which it occurred. The most extensive loss happened during colonial times however, losses continue to this day due to various government land management policies and practices. Consequently, the Swift Parrot remains the subject of an ongoing national recovery program and its future is far from secure.

Key Words: Swift Parrot, Lathamus discolor, colonial art, migration, habitat loss, forestry, agriculture, development, legislation, climate change, conservation.

\section{INTRODUCTION}

Swift Parrots, Lathamus discolor White, 1790, are nectarivorous birds of the family Psittaculidae that have attracted much attention with their charismatic behaviour, melodious calls and colourful plumage (Gould 1848). The Swift Parrot forages on nectar and lerp in the woodlands and forests of southeastern Australia and migrates each year between breeding habitat in Tasmania and wintering habitat in southeastern mainland Australia (Juniper \& Parr 1998) (fig. 1).

Although images of Swift Parrots from the late eighteenth and nineteenth century (e.g., pl. 1) provide an indication of their presence in habitats around Sydney and Hobart, further details on the natural history of this species were not available until John Gould (1848) published The Birds of Australia and Adjacent Islands (pl. 2). The valuable ecological information he provided, 50 years after the species was first described, included descriptions of food sources, flocking and foraging behaviour, and habitat.

Throughout the eighteenth and nineteenth centuries, information on abundance was limited to observations such as those by Gould (1848) who remarked on the great abundance of small flocks around Hobart. An interesting aspect of Swift Parrot migration, first noted in the early twentieth century, was its variability (Batey 1907) with large flocks appearing in response to abundant food resources into areas where they had been absent for years (Hindwood \& Sharland 1964). Such variable habitat use has continued throughout the twentieth and twenty-first centuries (Saunders \& Tzaros 2011). This includes large influxes of Swift Parrots in coastal habitats of New South Wales in the 1930s, 1950s (Hindwood \& Sharland 1964) and 1960s (Bill Boyd pers. comm.) where flocks of up

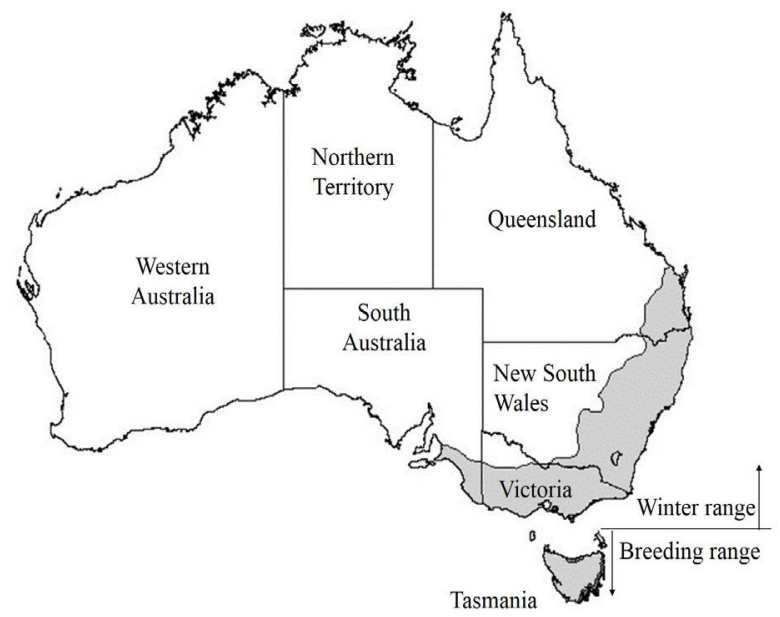

FIG. 1 - Distribution of the Swift Parrot in southeastern Australia

to 2000 birds were recorded as foraging at sites for up to three months, but then not seen again for many years.

Although these irruptions have previously been considered unpredictable (Hindwood \& Sharland 1964), it now appears that they may be the result of extreme drought conditions in some parts of the species' range, as demonstrated more recently by Saunders et al. (2016).

Although the anecdotal nature of these records and the variability of habitat use by the species limit inference with regard to population trends, they provide valuable insights into the flocking behaviour and their irruptive nature in some years. For example during the 1966 influx the maximum flock sizes were up to three times those of the influx in 2002 when the largest flock of 650 birds were observed (pers. obs.) despite hundreds of targeted surveys in the area and across their range. 

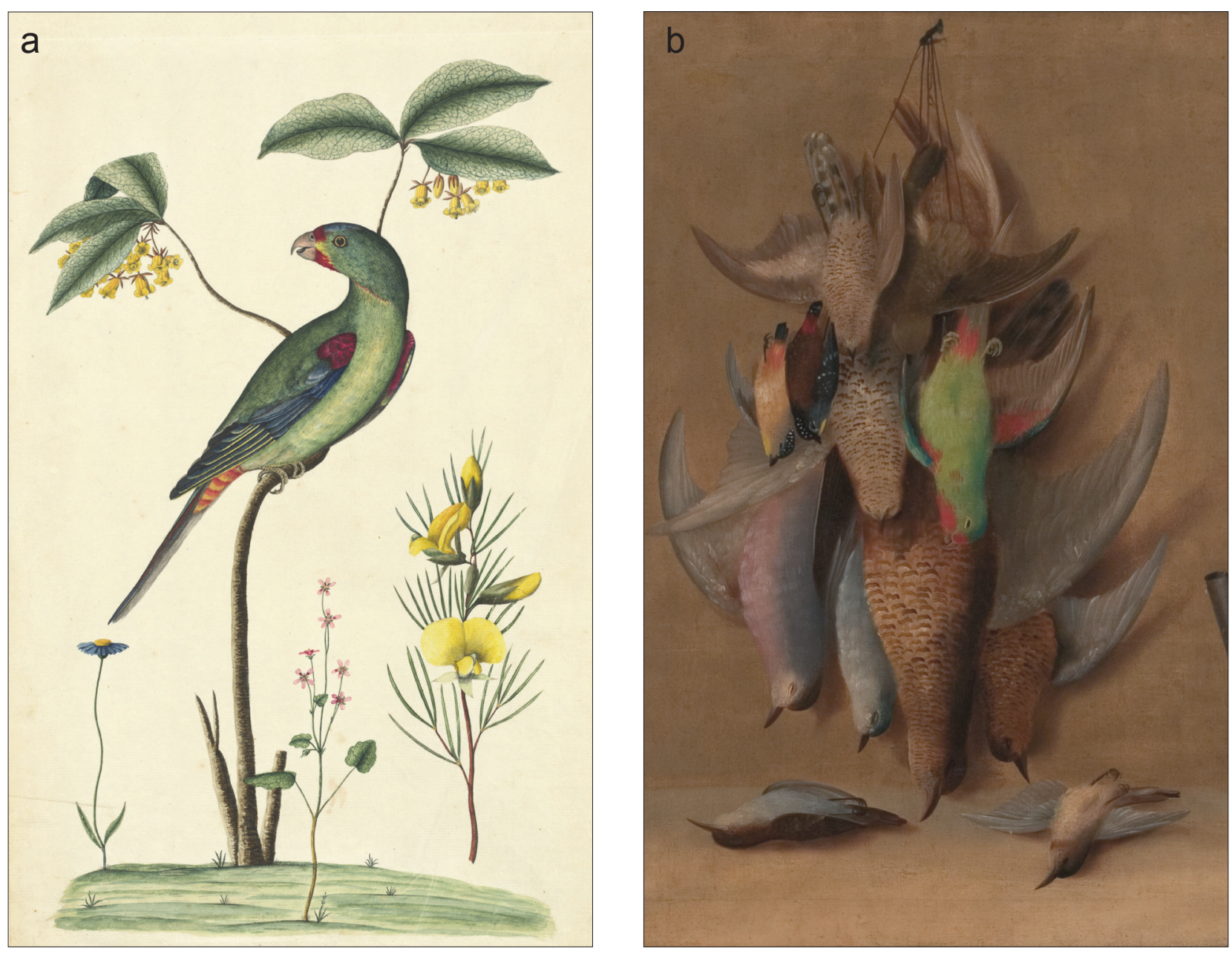

PLATE 1 - (a) Swift Parrot (Lathamus discolor) (c. 1789) by George Raper (Source: National Library of Australia, Canberra; reproduced with permission); (b) Birds by William Buelow Gould (1840s) (Source: Art Gallery of Ballarat, gift of Mr and Mrs Wallace White, 1980, Ballarat; reproduced with permission).

In the late twentieth century Brown (1989) provided a comprehensive report on the natural history of Swift Parrots, including further detailed information on habitat, food resources and the first assessment of population size, which was calculated as 1320 breeding pairs. These data provided a baseline to compare future population estimates and in the 1995/96 breeding season only 940 breeding pairs were detected, representing a severe decline (29\%) (Saunders \& Tzaros 2011). With a small population size, limited breeding range and ongoing threats to their habitat Swift Parrots were recognised as a threatened species in 1995 , triggering the development of a recovery program (Brereton 1996).

Almost 20 years later, with fresh evidence of a rapidly declining population (Heinsohn et al. 2015), the species' status has now been revised as Critically Endangered on the International Union for Conservation of Nature (IUCN) Red List of Threatened Species (IUCN 2015) as well as on the national Environment Protection and Biodiversity Conservation Act 1999 (EPBC Act).

Although a number of threats to this species have been identified (Brown 1989, Saunders \& Tzaros 2011), habitat loss remains one of the most significant threats. However, historical information on the timing, extent and causes of this loss has not previously been examined. A greater understanding of the spatial and temporal extent of impacts on Swift Parrot habitat will result in an improved understanding of the factors impacting on remaining habitats and aid research and conservation management efforts (Lunt \& Spooner 2005).

\section{HISTORIC HABITAT LOSS (18th AND 19th CENTURIES)}

Within 60 years of European settlement in Australia, habitat throughout the Swift Parrot's migratory range was being cleared. This was during Australia's exploitative pioneering era, when forests and woodlands were seen as an inexhaustible resource and the government supported progress, growth and development of the land without consideration of environmental effects (Frawley 1994). The loss of habitat extended from the Swift Parrot's breeding range in southeastern Tasmania, through to the wintering habitat across southeastern mainland Australia (fig. 2). 


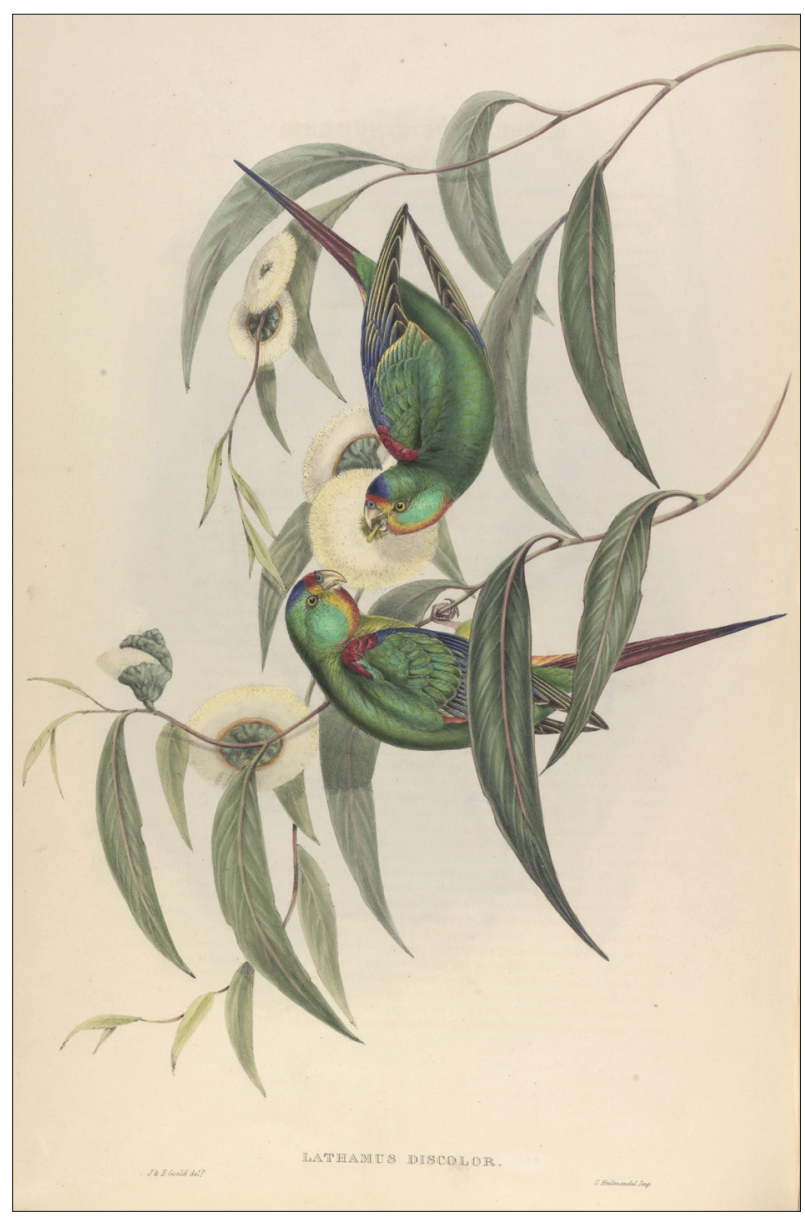

PLATE 2 - Swift Parrots in Eucalyptus gibbosus [now Eucalyptus globulus] from John Gould's (1848) book Birds of Australia and Adjacent Islands (Source: Australian National University Menzies Rare Book Collection, Canberra; reproduced with permission).

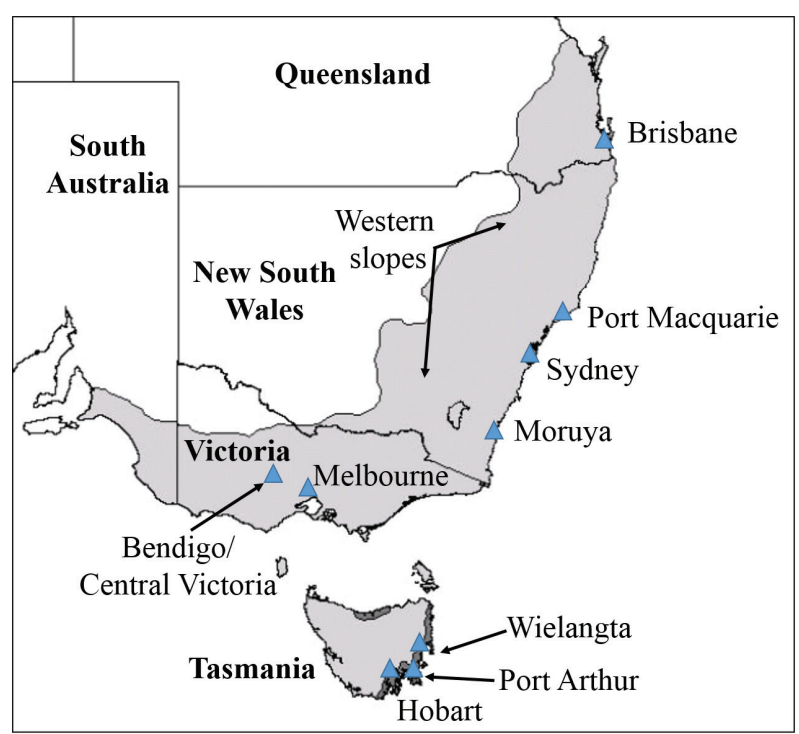

FIG. 2 - Key historic localities within the Swift Parrot range noted in this research.

\section{NEW SOUTH WALES (EUROPEAN SETTLEMENT FROM 1788)}

The first European colony was established in 1788 at Sydney Cove, within the wintering range of the Swift Parrot (fig. 2 ). To early pioneers, areas of native vegetation needed to be cleared to make the land productive (Cubit 1996) resulting in clearing for agriculture, grazing and timber resources (Carron 1985). One of the artists who painted Swift Parrots in the late eighteenth century, Thomas Watling, also did some drawings of the landscape around the colony, providing some insight into the extent and type of clearing of vegetation for the settlement. In general, large areas were entirely cleared of native vegetation, however, sometimes isolated old trees were left scattered around the edges of the settlement (pl. 3).

From first settlement to the end of the eighteenth century extensive, indiscriminate felling of timber trees occurred in a largely wasteful manner (Grant 1989) including areas known to contain habitat suitable for Swift Parrots. The extent of destruction of forested lands, such as those around the Nepean River, South Creek and George's River, prompted Governor Hunter to introduce the first timber regulations in 1795, although in reality they had little effect (Grant 1989). These areas were then included on a map of settlement growth districts in 1810 (pl. 4), and large areas of woodland containing Swift Parrot forage tree species continued to be cleared, despite further attempts to control such activity (Carron 1985). As a result, in 1898 it was noted that the once regularly occurring Swift Parrots around the Rooty Hill area of Sydney were now seldom seen (North 1898) (pl. 4).

In 1826, Governor Darling issued an order that selection and settlement of land was to be confined to a defined section of New South Wales. The "Limits of Location" were from Port Macquarie in the north to Moruya in the south and extending inland to the Liverpool Range and Yass (Wadham 1967, Grant 1989). Subsequently Swift Parrot habitat within both coastal and inland areas of the settlement limits was heavily impacted, e.g., John Gould first observed the species in its winter habitat in the Upper Hunter River district during a severe drought within an area that was extensively grazed by thousands of sheep and cattle (Datta 1997).

Coastal habitats within the specified limits would have been impacted upon concurrently by a number of settlements including Port Macquarie (1821) and Port Stephens (1826) on the north coast (Grant 1989) and Batemans Bay and Moruya (1820s) on the south coast (Turner 1996) (pl. 5). These settlements were established in areas that contain key forage tree species for Swift Parrots including Forest Red Gum Eucalyptus tereticornis Smith, Swamp Mahogany Eucalyptus robusta Smith, Spotted Gum Corymbia maculata Hill \& Johnson and Blackbutt Eucalyptus pilularis Smith (Saunders \& Tzaros 2011). As a result, within the first 50 years of European settlement, all major coastal habitat types known to be used by the Swift Parrot in New South Wales had been either cleared or altered to some extent. 


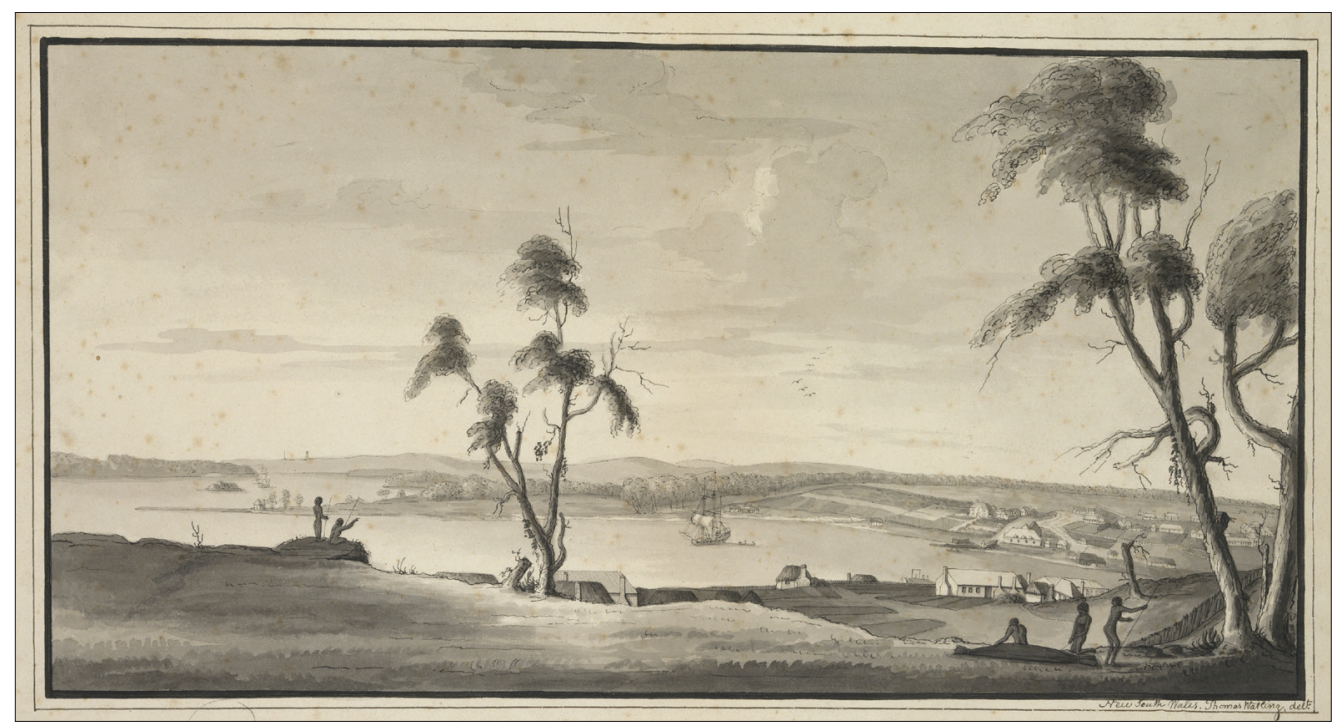

PLATE 3 - North-West View taken from the Rocks above Sydney Cove in New South Wales, by Thomas Watling (1793-1795) for John White (Source: State Library of NSW; reproduced with permission).
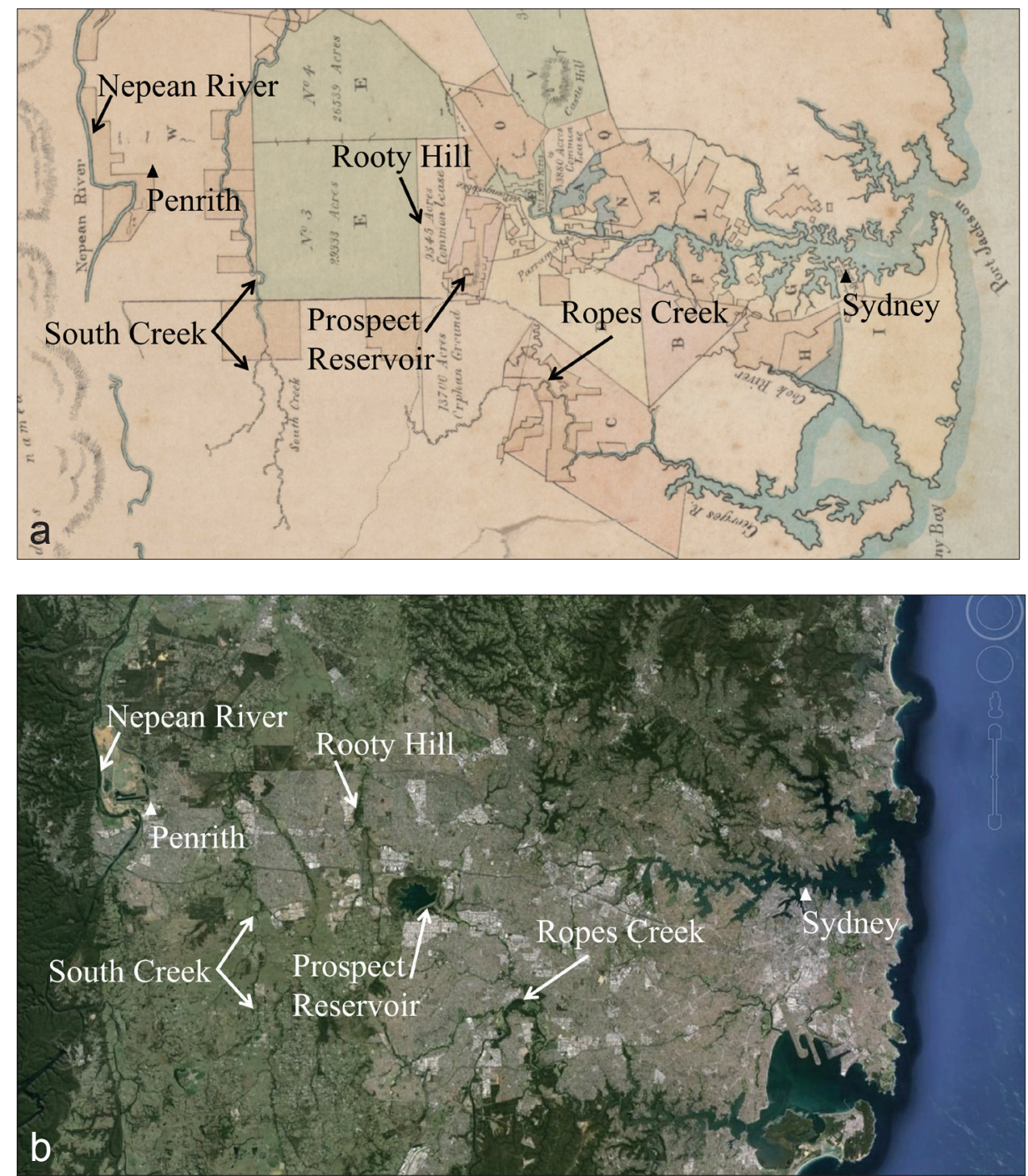

PLATE 4 - The Cumberland Plain area of western Sydney in (a) 1810, a new plan of the settlements in New South Wales: taken by order of Government, July 20th 1810, published by John Booth (1810), reproduced by William Dymock (1870-1899) (Source: National Library of Australia, Canberra; reproduced with permission) and (b) 2007, aerial photograph of Sydney showing extensive urban development across areas previously used by Swift Parrots (remnant habitats are small dark patches, large dark patch near Rooty Hill is Prospect Reservoir) (Google 2015). 
Under regulations introduced in 1820 , timber-getters needed permission to operate and remove specified quantities of timber. However, by 1870 the continued, unregulated felling of trees was considered a threat to future wood supplies and eventually resulted in the establishment of some of the first forestry reserves in New South Wales (Carron 1985).

The Liverpool Plains on the northwestern slopes of the Great Dividing Range marked the western boundary of the limits of settlement and were discovered by Europeans in 1823. The plains are among the most fertile and productive agricultural lands in Australia, and by 1831 squatters were establishing pastoral and agricultural areas (Halliday 2005). Squatters continued to spread across the western slopes of the Great Dividing Range to occupy extensive grazing areas beyond the specified limits (Grant 1989), gradually impacting on various types of grassy woodlands which included Swift Parrot forage tree species such as Mugga Ironbark Eucalyptus sideroxylon Woolls, White Box Eucalyptus albens Miquel, Grey Box Eucalyptus microcarpa Maiden and Yellow Box Eucalyptus melliodora A.Cunn. ex Schauer (Kennedy \& Overs 2001, NSW Scientific Committee 2001, 2002, 2006, Saunders \& Tzaros 2011). Grazing and clearing of native vegetation continued for much of the remainder of the nineteenth century with native vegetation being retained in increasingly small patches largely limited to travelling stock routes and road reserves (NSW Scientific Committee 2001) (pl. 6).

\section{TASMANIA (EUROPEAN SETTLEMENT FROM 1803)}

As the winter foraging habitats of Swift Parrots were being increasingly lost in New South Wales, the establishment of Hobart Town in 1803 resulted in additional loss of habitat in the heart of the Swift Parrot breeding range on the Tasmanian east coast. In similar fashion to the expansion of the settlement at Sydney Cove, as soon as Europeans settled in Hobart, clearing of native vegetation occurred (Carron 1985). Timber-getting became an important activity, starting with the eucalypts around the Derwent estuary. This included the harvesting of Tasmanian Blue Gum Eucalyptus globulus Labill. and Brown-top Stringybark Eucalyptus obliqua, L'Herit. which are prized for their high quality timber (Carron 1985), and provide important breeding habitat for Swift Parrots (Saunders \& Tzaros 2011).

The image of Hobart Town in 1868 (pl. 7a) illustrates the development of the Derwent River foreshore and the image of Derwent Park in the 1800s (pl. 7b) provides an example of clearing on the upper reaches of the Derwent River with Mt Wellington in the background, which was a popular area for collecting Swift Parrots (Gould 1848, Datta 1997). The loss of breeding habitat also occurred in other coastal settlement areas of eastern Tasmania, such as around the Port Arthur penal colony (established in 1830), on the south coast and on offshore islands where manufacturing enterprises such as ship building, blacksmithing and brick making were burgeoning and utilising timber from the surrounding forests (PAHSMA 2007). However isolated trees and some patches of native vegetation remained in the areas surrounding settlements, which would have continued to provide at least some limited foraging habitat for Swift Parrots (pl. 8).

The demands for timber, as well as cleared land for settlement, agriculture and grazing increased the pressure on Swift Parrot breeding habitat. By 1835, virtually all of the open grasslands and grassy woodlands of Tasmania had been occupied and given over to the production of wool and wheat. Legislation such as the Waste Lands Act 1858 was devised to encourage this selection and development of forested areas for agricultural purposes. Although in the

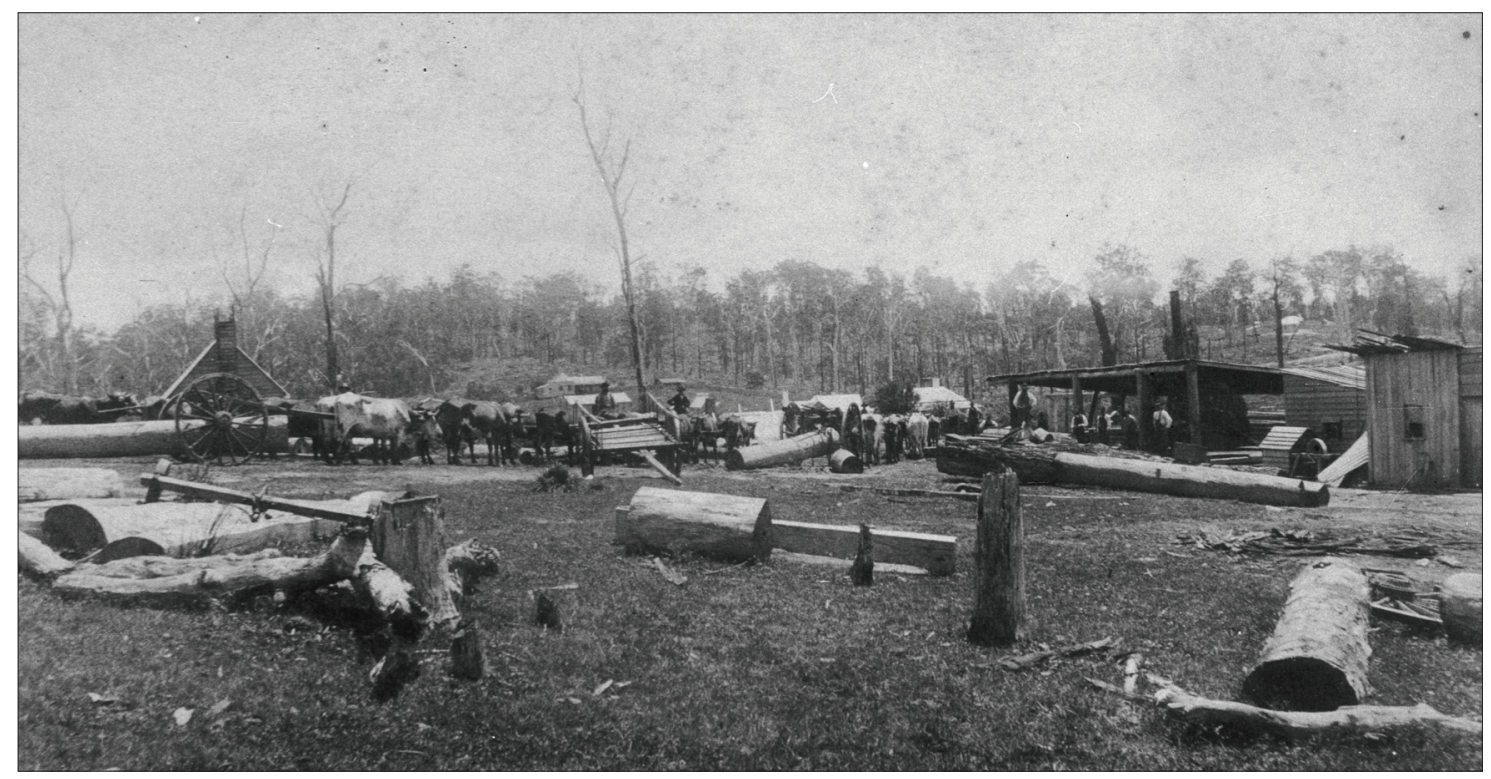

PLATE 5 - Historic clearing of coastal forests near Tanja (Bega) (Unknown Photographer 1877-), on the south coast of New South Wales (Source: State Library of NSW, Sydney; reproduced with permission) 


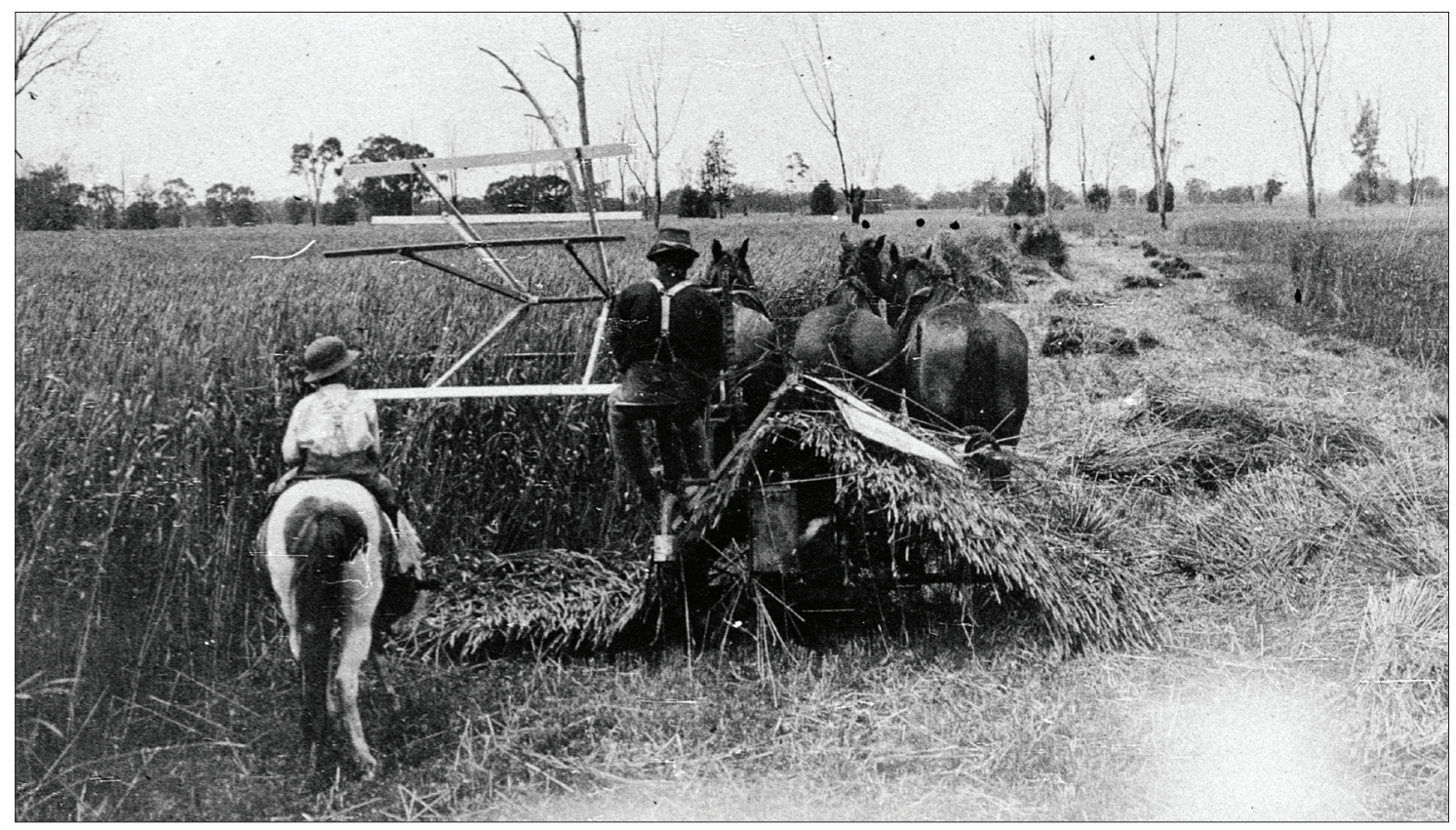

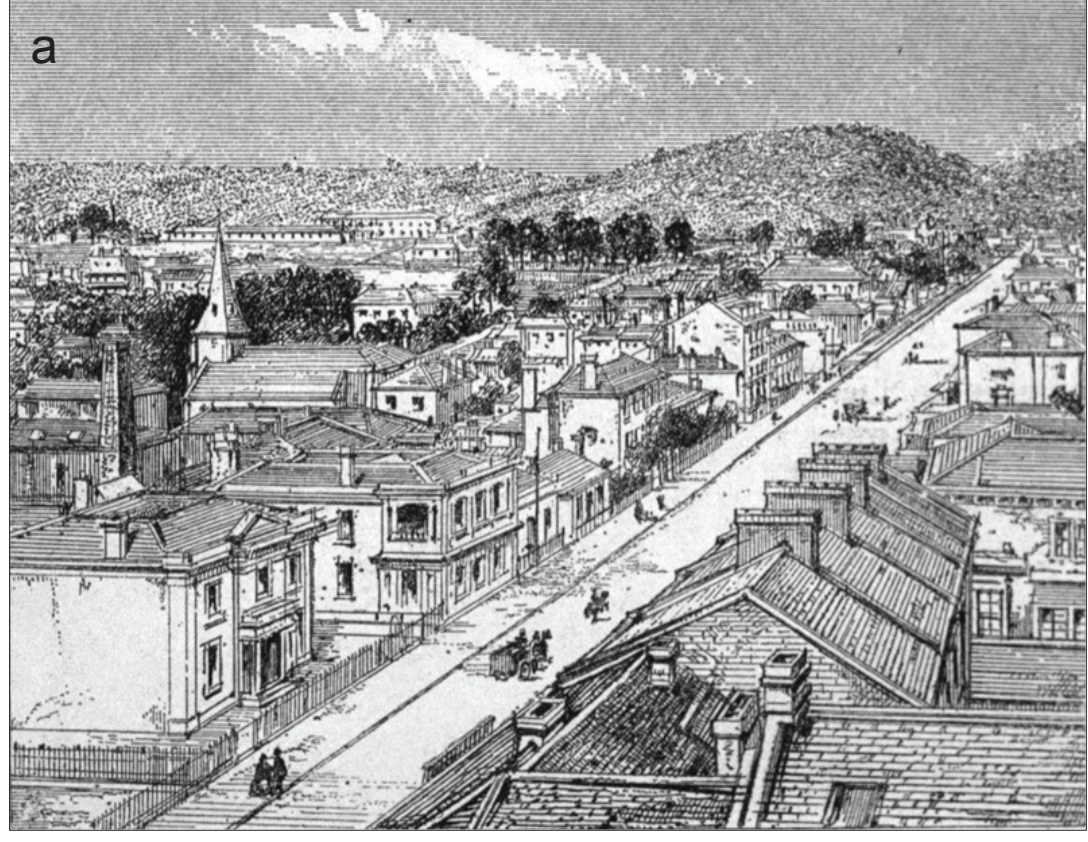

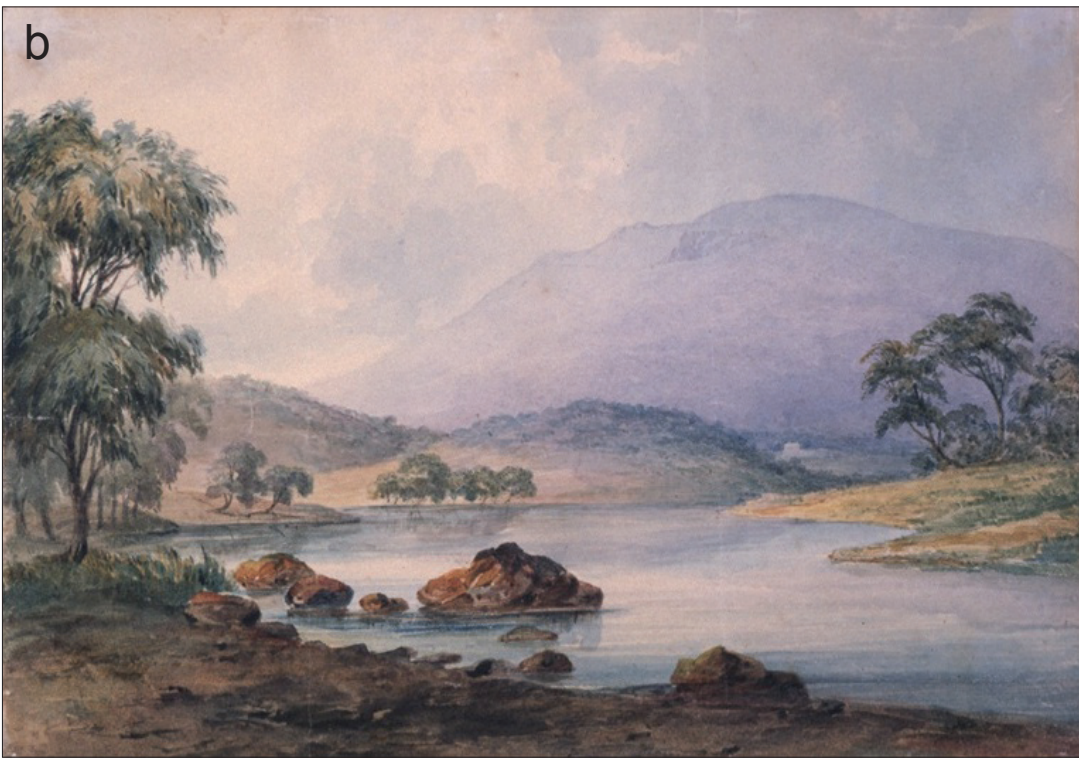

PLATE 6 (above)- Historical clearing of woodlands for agriculture on the western slopes of New South Wales with a narrow strip of trees retained in the background '7ft high wheat crop on "Kia Ora", GroganGrogan, Temora area, NSW' (Unknown Photographer 1880-1940) (Source: State Library of NSW, Sydney; reproduced with permission).

PLATE 7 - (a) Hobart Town, from the tower of St David's Church by Hugh Munro Hull (1859) (Source: State Library of Tasmania, Hobart; reproduced with permission);

(b) At Derwent Park, New Town, V.D.L. by T.E. Chapman (1835-1860) (Source: State Library of Tasmania, Hobart; reproduced with permission). 
1880s concerns began to be expressed about the cumulative impacts on Tasmanian forests from uncontrolled logging, land clearing and frequent and uncontrolled fires, these activities continued largely unchecked until the end of the century (Cubit 1996). Concerns were raised over the depleted timber resources and impacts to the Tasmanian Blue Gums in particular where it was noted that they could not survive repeated firing of the undergrowth (Innes 1896).

The Tasmanian Blue Gum, is an integral component of the Swift Parrot breeding habitat (Brown 1989) and measures to reduce such destructive forestry practices in Tasmania were not enacted until 1919 when Conservators of forests were appointed and the Forestry Act 1920 was introduced (Cubit 1996).

\section{VICTORIA (EUROPEAN SETTLEMENT FROM 1835)}

Major habitat loss occurred again with the settlement of Melbourne in 1835. Within ten years, key habitat north of Melbourne was subject to rapid population increase (Powell 1969), including a core part of the Swift Parrot wintering range in central Victoria. This was followed by an even greater human population explosion, and corresponding destruction of native forests when gold was discovered in 1851 (Carron 1985) in the heart of the Swift Parrot winter habitat around Bendigo. Within eight years there were half a million people in Victoria (Commonwealth of Australia 2006a) and the demand for wood was voracious. This proved to be the most devastating loss of Swift Parrot habitat in the mid nineteenth century, and eliminated almost all old growth trees in the Box-Ironbark forests of Victoria (Environment Conservation Council 2001). Although legislation and licensing were eventually established, there were no restrictions on tree species, sizes or quantity of timber harvested (Carron 1985). The Box-Ironbark forests were extensively damaged during the gold rush period (Environment Conservation Council 2001) (pl. 9), with indiscriminate clearing of species such as Red Ironbark Eucalyptus tricarpa Hill \& Johnson, Mugga Ironbark E. sideroxylon, Grey Box E. microcarpa, Yellow Gum Eucalyptus leucoxylon Mueller, and Yellow Box E. melliodora, which provide vital habitat for Swift Parrots.

The extent to which the forests were being exploited, both legally and illegally, continued throughout most of the latter part of the nineteenth century (Victoria Parliament $1865,1874)$ and evidence of this remains today with the almost complete absence of old growth trees (Environment Conservation Council 2001). The extent of unnecessary damage to the forests was highlighted in a report by Inspector-General Ribbentrop of the Indian Forest Service in 1896, which stated that the state forest conservancy and management in Victoria were in an extraordinarily backward state, with inadequate laws, funding, revenue and reserve establishment as well as rampant waste and destruction by fire (Ribbentrop 1896).

Given the extreme and rapid destruction of forests in Victoria, an attempt was made to curtail the reckless exploitation of native forests by appointing Conservators of Forests and establishing the Forestry Act 1907 (Carron 1985). However, despite the large scale habitat clearance that occurred in the mid-1800s, in the early 1900s Batey (1907) noted that Swift Parrots were still frequent visitors to Yellow Box habitats.

\section{ONGOING HABITAT LOSS (20th AND 21st CENTURIES)}

In the twentieth century new concepts such as "wise use" management of natural resources were introduced, however the first half of this century was dominated by two world wars, post-war reconstruction and an economic depression. As a result, the utilitarian ethos of "progress through

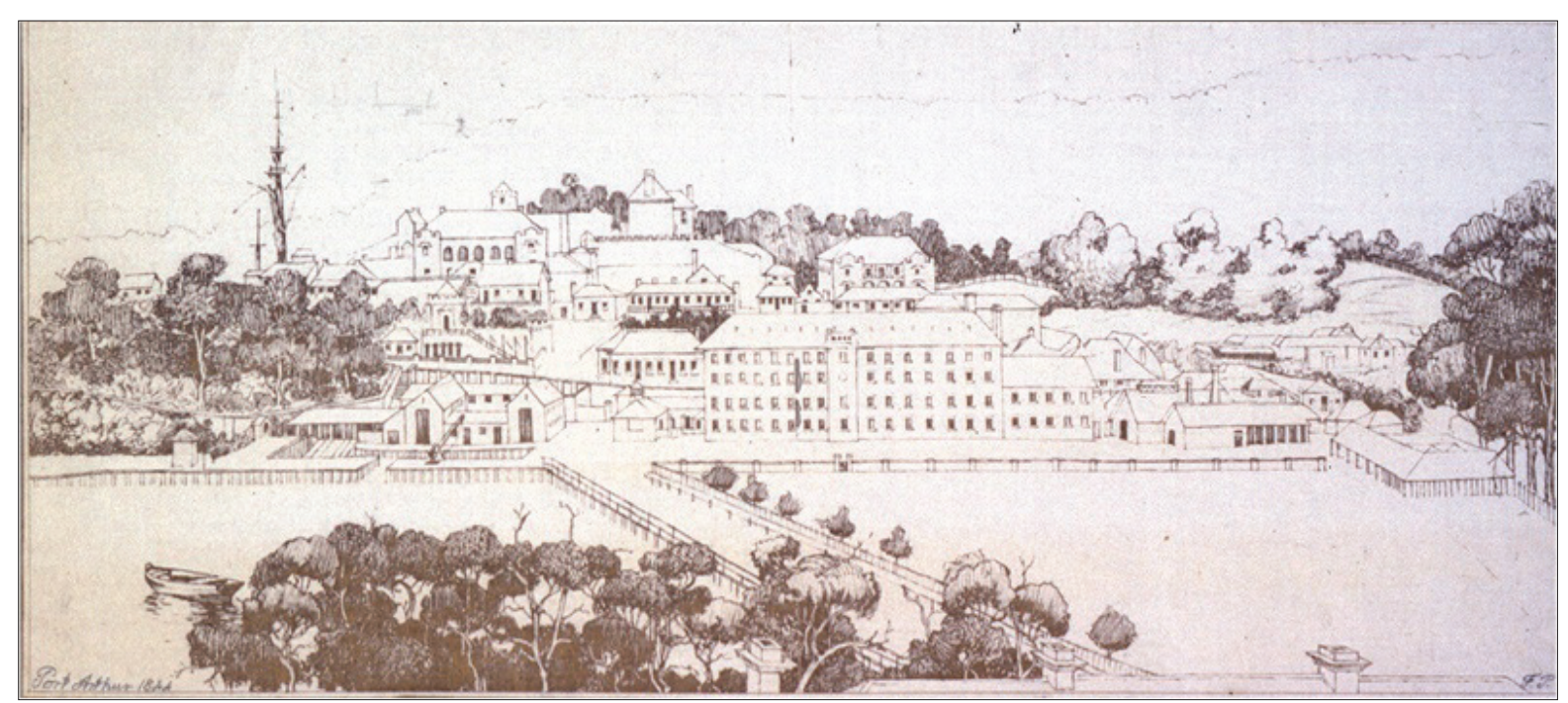

PLATE 8 - Port Arthur 1844 by Tasmanian Lands Department (1917) (Source: Allport Library and Museum of Fine Arts, State Library of Tasmania, Hobart. Reproduced with permission). 

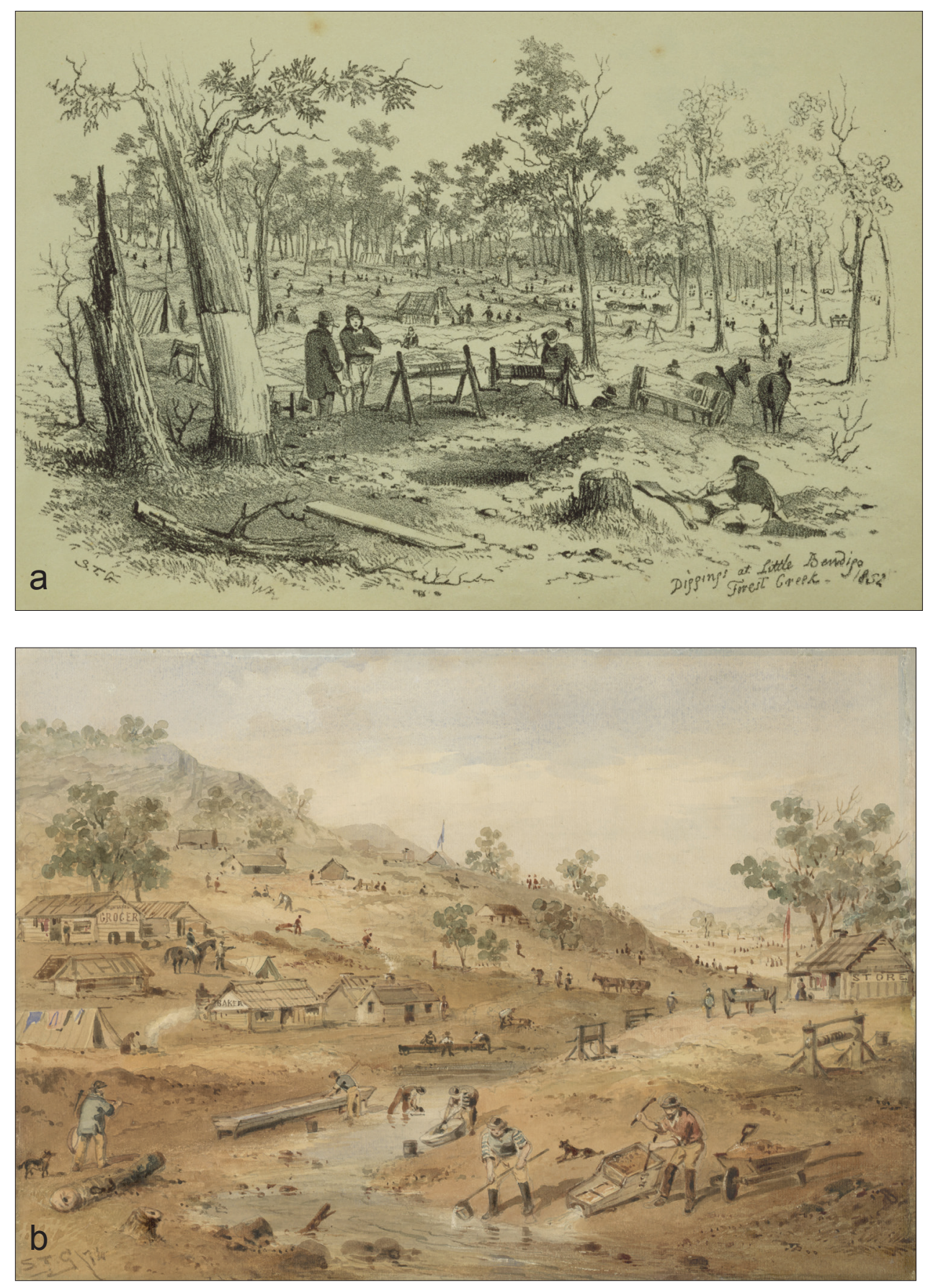

PLATE 9 - Extensive habitat loss in central Victoria. (a) Diggings at Little Bendigo, Forest Creek, 1852 by S.T. Gill (1855) (Source: National Library of Australia, Canberra; reproduced with permission). (b) Mt Alexander 1852 by S.T. Gill (1874) (Source: National Library of Australia, Canberra; reproduced with permission).

development" continued to dominate the management of lands and forests (Frawley 1994). For example, the intensification of rural land settlement continued with little prior economic or environmental analysis, and forests continued to be cut at levels beyond long-term sustainability (Resource Assessment Commission 1990). However, in response to the growing conflict between environmental values and resource development in the 1960 s, environmental protection and planning were progressively incorporated into state and federal government legislation (Frawley 1994).
The emphasis on environmental issues continued to grow over the next two decades with environmental strategies developed at national and international levels (IUCN et al. 1980, Commonwealth of Australia 1983), and the introduction of numerous pieces of environmental legislation at both national and state levels (Grinlinton 1990, Frawley 1994) throughout the Swift Parrot range. In the late 1980s, and throughout the 1990s environmental strategies became focused on Ecologically Sustainable Development principles (Ecologically Sustainable Development Steering Committee 1992), and legislation 
was introduced for the protection of native vegetation and threatened species (e.g., Victorian Flora and Fauna Guarantee Act 1988 (FFG Act), NSW Threatened Species Conservation Act 1995 (TSC Act), Tasmanian Threatened Species Protection Act 1995; and Commonwealth EPBC Act 1999) (Bates 2006). This included listing of the Swift Parrot as a threatened species at national and state levels.

Brown (1989) and Brereton (1996) identified habitat loss as the single largest threat to the Swift Parrot, and this continues to be the case into the twenty-first century (Saunders \& Tzaros 2011) despite the introduction of legislative frameworks and recovery plans to protect the Swift Parrot. Although there have been some advances in the conservation of this species (Saunders et al. 2007), various land use practices such as forestry, agriculture, pastoralism, mining and urban development continue to impact this species' habitat (Saunders 2002, Marshall 2006, Saunders \& Tzaros 2011, Allchin et al. 2013, Stojanovic et al. 2014).

The extent of habitat loss for the Swift Parrot has been so severe that a number of key habitats are now classified as endangered ecological communities with as little as 5-15\% remaining (NSW Scientific Committee 1997, Commonwealth of Australia 2000, 2002, 2004, 2005). However, the value of these remnants remains high given they often provide the only foraging resources for the species within an otherwise cleared landscape (Saunders \& Heinsohn 2008, Saunders et al. 2016). Since the original extent of Swift Parrot habitat and the subsequent habitat loss in each state has never been quantified, despite being a key action in the national recovery plan (Saunders \& Tzaros 2011), there are currently no baseline data to fully understand the true extent of historic, current and ongoing habitat loss.

\section{FORESTRY}

Following on from the initial forestry Acts of the early twentieth century, various state forestry organisations were becoming more interested in a national outlook, with greater emphasis on the need for special forest legislation, permanent and inalienable reserves, and the creation of permanent management authorities with statutory powers (Carron 1985). Reserves were initially established to ensure future timber supplies, however, over time, other forest values, such as habitat value for threatened species, became more widely recognised (Frawley 1994).

Years of conflict and disputes occurred over the values and use of forests, resulting in the Australian government's attempt to resolve the issue by producing the National Forest Policy Statement (Commonwealth of Australia 1992). The statement included the establishment of Regional Forest Agreements (RFAs) which were intended as 20-year plans for the conservation and sustainable management of forests (Commonwealth of Australia 2008). Of the 10 RFAs established, nine have potential implications for Swift Parrot habitat. Although the RFA process substantially increased the total area of forest in conservation reserves (Commonwealth of Australia 2008), the protected areas were based upon forests that had already been impacted by many years of mismanagement, and the logging of old growth forest was still permitted in Tasmania (Bates 2006). It should also be noted that the RFA process generally did not deal with private lands or plantation forests, and was limited in terms of landscape scale conservation given it was implemented on a region by region basis. Therefore only limited Swift Parrot habitat was protected under the RFA and the old growth forests containing important nesting and foraging habitat continue to be cleared (Saunders \& Tzaros 2011, Gramenz 2016). RFAs and associated licenses include detailed prescriptions for the retention and protection of threatened species habitats within timber harvesting areas, however they have proven to be largely inadequate for the Swift Parrot (Munks et al. 2004, Marshall 2006).

Swift Parrot habitat within production forests is afforded different levels of protection in different areas. Within key regions of Victoria, such as the Bendigo Forest Management Area, Swift Parrot Management Areas were established at 40 priority sites. In 2002, 23 of these sites were included in the conservation reserve system as part of the Box-Ironbark Investigation (Department of Natural Resources and Environment 2002a) (Environment Conservation Council 2001). A further seven sites were partially included in the conservation reserve system and the remaining 10 sites were retained within production forest (Environment Conservation Council 2001, Department of Natural Resources and Environment 2002a). Forestry operations within these remaining Swift Parrot Management Areas are required to retain all trees greater than $80 \mathrm{~cm}$ Diameter at Breast Height $(\mathrm{DBH})$ as well as two trees per hectare for the remaining three tree size classes $(60-80 \mathrm{~cm}, 40-60 \mathrm{~cm}$ and $20-40 \mathrm{~cm})$, however, in other regions of Victoria the required level of habitat retention is less rigorous (Department of Sustainability and Environment 2003).

In NSW production forests, habitat protection is not required unless there are Swift Parrot records at a particular location. However, even when there are records, only 10 trees (with no specification of minimum size) need to be retained for every two hectares of net logging area (NSW Department of Primary Industries 1999). Despite increasing knowledge of the importance of winter habitat for Swift Parrots in production forests of NSW (Kennedy \& Overs 2001, Saunders 2008) and repeated expert advice to amend the forestry prescriptions as the RFAs have come up for review (Saunders 2010), no suitable forestry prescription amendments have been made. On the western slopes of NSW however, a number of important remnant habitats that were previously state forests have incrementally been incorporated into the conservation reserve system over the past 15 years (e.g., Livingstone and Benambra National Parks created in 2001, Jindalee National Park in 2011).

However, of greatest concern are the ongoing impacts from timber harvesting practices in Tasmania, where the Swift Parrots are entirely dependent on old growth forest 
for nesting during the breeding season (Voogdt 2006, Webb et al. 2012). Despite the growing knowledge of the species' breeding biology and ecological requirements (Stojanovic et al. 2012, Webb et al. 2014, Stojanovic et al. 2015) this habitat continues to be approved for clearing (Tasmanian Government 2005, Marshall 2006, Australian Government 2011, 2013, NSW Government 2013) despite directly conflicting with expert advice and the objectives of ecologically sustainable forest management (Pullinger 2015) (pl. 10). For example, Stojanovic et al (2014) clearly demonstrate the extreme cumulative impact on the Swift Parrot from forest management practices that reduce the amount of mature habitat available.

The Forest Practices Authority is an independent statutory body that administers the Tasmanian Forest Practices Code (FPC) on both public and private land. Its primary responsibility is regulating the management of forest vegetation with the objective of achieving sustainable management of public and private forests with a duty care policy for the environment (Forest Practices Authority 2015). However, concerns have been raised in relation to this duty of care policy with the commercial objectives of the FPC seen as contrary to sustainable forest management practices since it does not maintain "viable breeding populations and habitat for all species" (EDO 2015).

In addition, the FPA is responsible for controlling land clearing on public and private land in Tasmania. Under the Permanent Native Forest Estate Policy, broad-scale clearing and conversion of native forest on public land was phased out in 2010, however broad-scale clearing and conversion of up to 40 hectares of native forest per property each year remains permissible in 2016 (Tasmanian Government 2016). Between 1972 and 1999, over a quarter of a million hectares of native vegetation were cleared in Tasmania (Kirkpatrick \& Dickinson 1982, Kirkpatrick 1991, Kirkpatrick \& Mendel 1999). The amount of native vegetation approved for conversion to plantation or non-forest use was 38550 hectares between 1999 and 2002 (Forest Practices Board 2000, 2001, 2002). However there is no single data source to report on land clearance and vegetation change in a systematic and consistent way for different land uses, vegetation types and tenures. Forest Practices Board data are used to provide a guide to forestry related clearance. However, these data are not mapped, do not include clearing occurring below thresholds of the Forest Practices System, and are not capable of monitoring illegal or incremental clearing. Clearance of vegetation communities for other uses such as housing is not measured or reported (Resource Planning and Development Commission 2003).

In addition to the direct impacts of habitat loss, as the amount of mature forest decreases due to timber harvesting, predation by the Sugar Glider, Petaurus breviceps Waterhouse, 1839 (an introduced pest in Tasmania) at Swift Parrot nests dramatically increases (Stojanovic et al. 2014). The extent of these impacts is so great that this species is now at imminent risk of extinction in the wild (Heinsohn et al. 2015). So, in the 100 years since forestry Acts were established in eastern Australia, forestry activities continue to have a severe impact on core areas of Swift Parrot habitat.

In relation to the protection of forests from 1996-2007, the Tasmanian government established the Protected Areas on Private Land Program (PAPL) and the Private Forest Reserves Program (PFRP) to extend the system of forest reserves on private land. This resulted in about 30000 hectares of forested land protected by conservation covenants (Resource Planning and Development Commission 2003). Bird Life Australia's ongoing Woodland Birds for Biodiversity Program, in collaboration with the NSW Nature Conservation Trust, Victorian Trust for Nature, Tasmanian Land Conservancy and the NSW Saving Our Species program, has protected key habitat

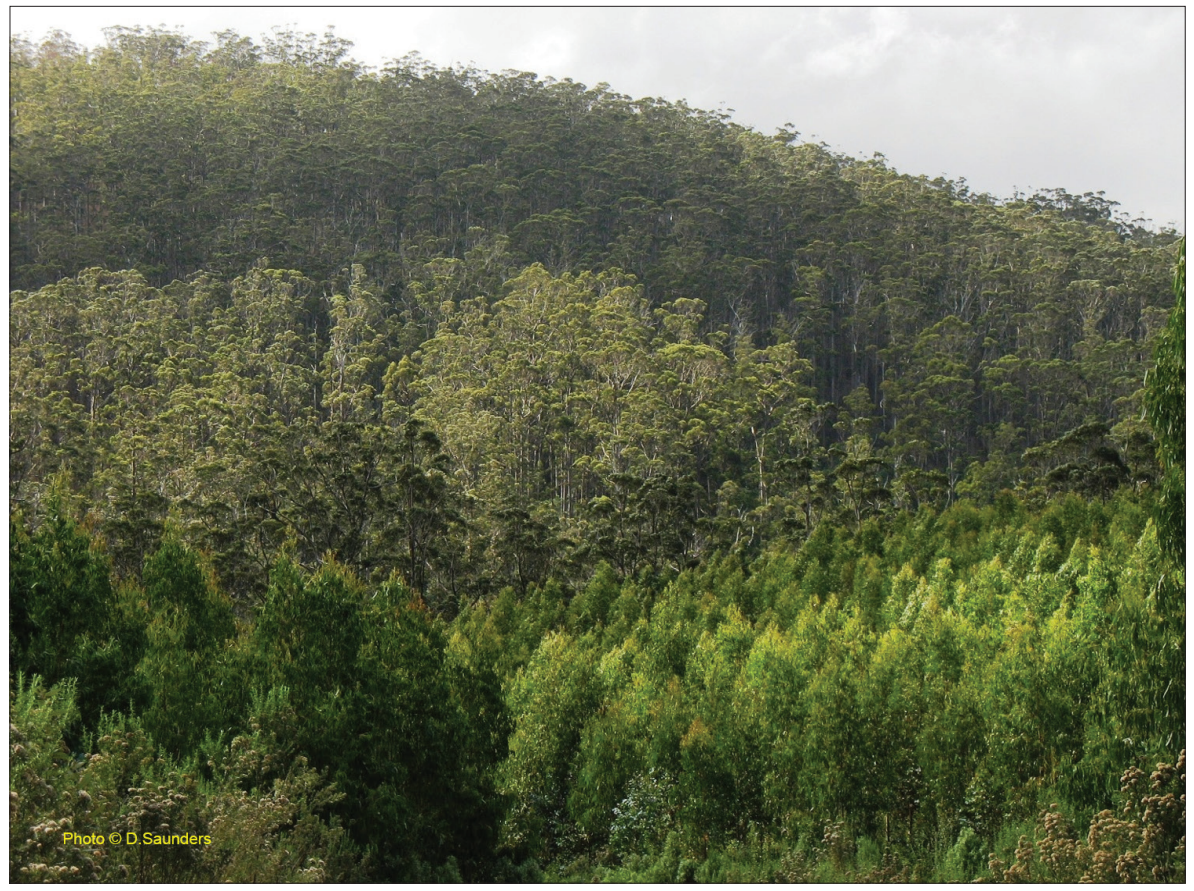

PLATE 10a - Ongoing conservation issues for the Swift Parrot. Wielangta Forest broadscale clear felling of old growth Swift Parrot breeding habitat (background) for conversion to younger "sustainable-harvest" plantation forest (foreground) (2007) (Photo: Debbie Saunders, private collection). 
by securing conservation covenants on 2700 hectares of significant woodland habitat throughout the Swift Parrot range (Ingwersen \& Tzaros 2011). To complement these conservation initiatives, a recent crowdfunded project has enabled the installation of hundreds of nest boxes for Swift Parrots on predator free islands in Tasmania in preparation for the 2016/17 breeding season. At the start of the first season since box installation, 25\% of the nest boxes are being used by Swift Parrots, increasing the capacity of this declining population to improve their breeding success (O’Connor 2016).

\section{AGRICULTURAL PRODUCTION}

Economic development in southeastern Australia in the nineteenth century resulted in the over-clearing of agricultural areas (Beeton et al. 2006) and left native vegetation confined to small, isolated remnants (Lunt \& Spooner 2005) (pl. 11). Many areas continued to be cleared of native vegetation while others suffer incremental loss of vegetation from management of the surrounding landscape, through senescence of old trees and reduced regeneration of new ones (Gibbons \& Boak 2002).

A National Framework for the Management and Monitoring of Australia's Native Vegetation was established in 2001 (Natural Resource Management Ministerial Council 2000) and revised in 2012 (COAG Standing Council on Environment and Water 2012). This framework required a commitment from all Australian, state and territory governments to reverse the long-term decline in quality and extent of Australia's native vegetation cover, and encouraging the protection, rehabilitation and restoration of native vegetation. Although the level of commitment within most of the Swift Parrot range was an improvement on past management practices (Department of Primary Industries Water and Environment 2000, Department of Natural Resources and Environment 2002b, Commonwealth of Australia 2006b, Ministerial Review Committee 2006, Natural Resources and Water 2007), clearing of old growth habitat continues to be an issue in Tasmania (Tasmanian Government 2005, Pullinger 2015).

Impacts on Swift Parrot habitat in NSW have been so severe that only $5 \%$ to $30 \%$ of the original vegetation now remains, such as for Grey Box, E. microcarpa, and Grassy White Box, E. albens, woodland, and what is left is often degraded (NSW Scientific Committee 2002, 2006). With such extensive losses of habitat there is an increased risk that the remaining areas may fail to produce the necessary food resources in one year, which may lead to rapid population decline due to the accumulated extinction debt (Kuussaari et al. 2009). That is, before such extensive habitat losses occurred, the birds had a much greater chance of locating the food resources they needed each year.

Many of the woodland remnants that remain occur within the extensive Travelling Stock Route (TSR) network of crown land and have great ecological value within the agricultural landscape (DECCW 2009). However the

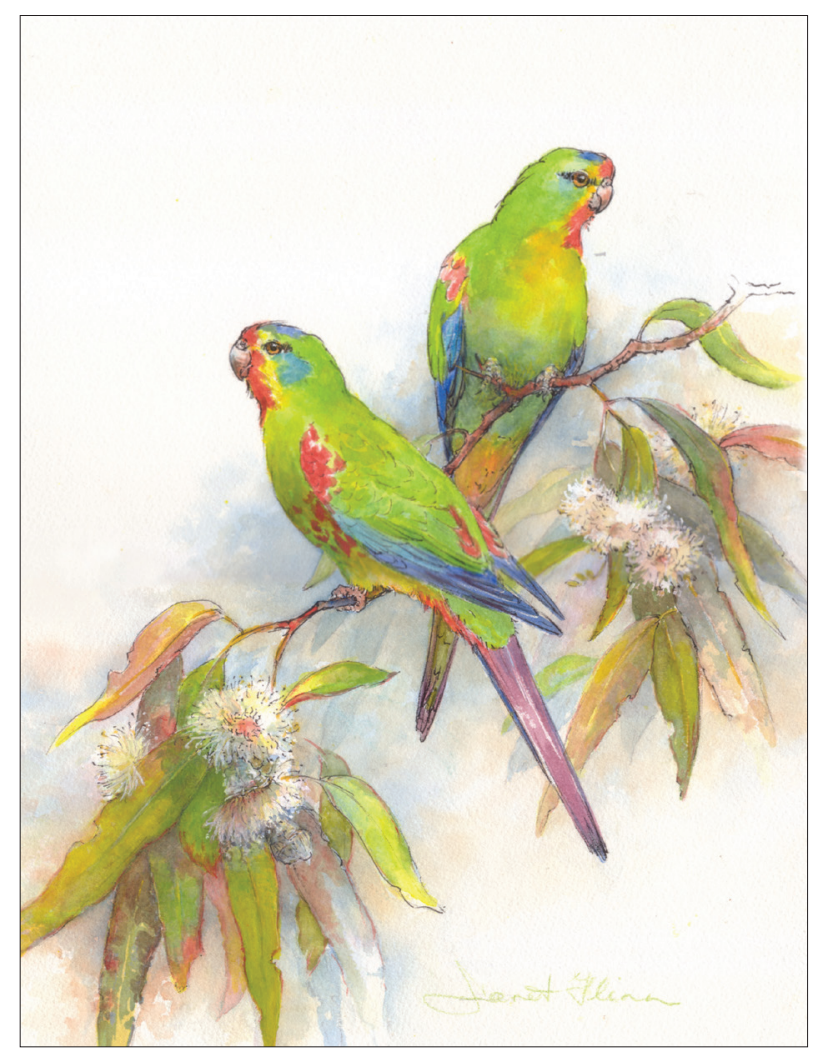

Plate 10b - Swift Parrots by Janet Flinn (2006). Water colour painting commissioned for fundraising purposes to help conserve Swift Parrot breeding habitat in Wielangta Forest, Tasmania. (Source: Debbie Saunders, private collection).

future management of TSRs is currently being evaluated as part of the NSW Travelling Stock Reserve Planning Framework (NSW Government 2014). Each of the NSW Local Land Service regions will assess the values and priorities of their local reserves and develop plans for the most appropriate future management (NSW Local Land Services 2015).

However, the NSW government is also currently in the process of reforming biodiversity management laws, with the aim of improving the policy, legislative, institutional and financial framework for biodiversity conservation. The reforms are also aiming to cut red tape, facilitate ecologically sustainable development and conserve biodiversity across NSW (State of NSW 2014). However, concerns have been raised about various detrimental aspects of the proposed reforms including the replacement of the Native Vegetation Act 2003 with the Local Land Services Amendment Bill that has no ban on broad-scale clearing and no "maintainor-improve" standard to ensure environmental outcomes which is likely to result in significant clearing increases in NSW. It is also seen to be heavily reliant on "offsetting" biodiversity impacts rather than preventing the impacts, and removes protections within the laws to prevent continued biodiversity decline (EDO 2016).

In Victoria, the Native Vegetation Management Framework (Department of Natural Resources and Environment 2002b) was established to achieve a reversal, across the entire landscape, of the long term decline in the extent 
and quality of native vegetation. This is now being implemented through Property Vegetation Plans (PVPs) whereby landholders outline the future management of native vegetation on their property (Department of Sustainability and Environment 2006b), and identify how they will offset the negative environmental impacts of proposed clearing by managing other native vegetation for conservation (Ministerial Review Committee 2006). Incentives are also being provided to landowners for conservation management and restoration of native vegetation (Department of Natural Resources and Environment 2002b). This has the potential to provide a range of benefits for the long term sustainability of

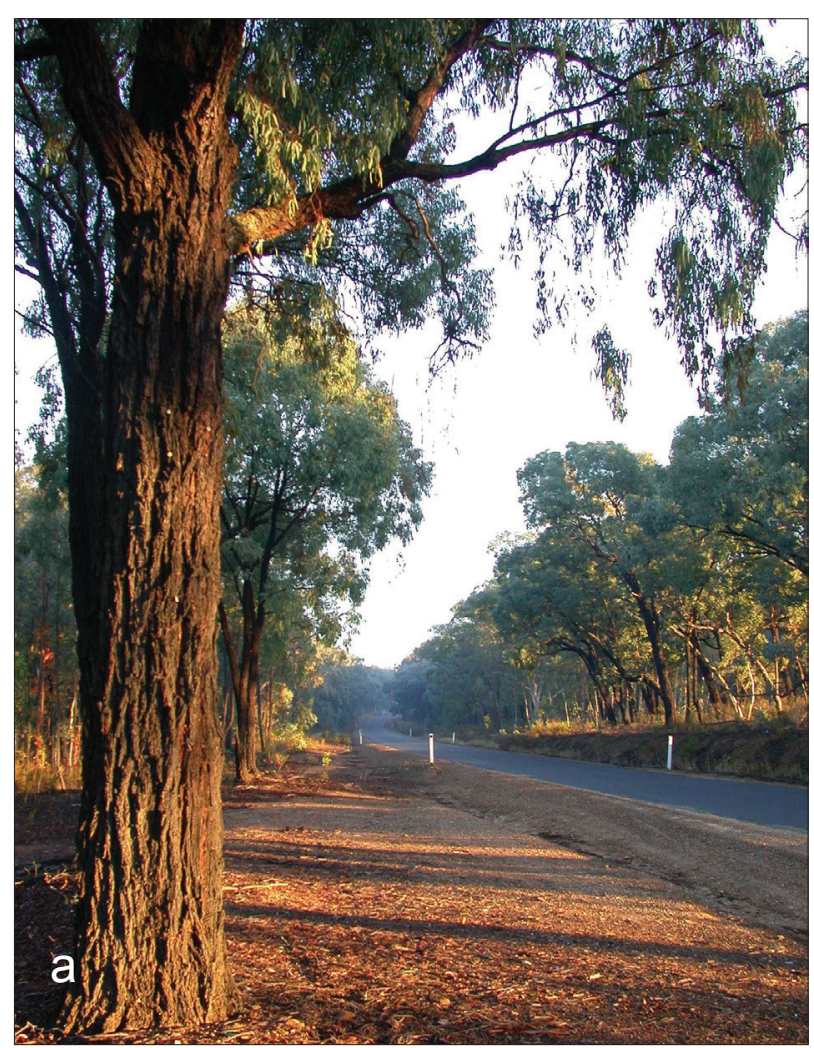

Swift Parrot habitat and similar arrangements have been established in other states as well (Department of Primary Industries Water and Environment 2000, Department of Natural Resources 2006, Ministerial Review Committee 2006, Environment Protection Authority 2007). These planning tools have the ability to integrate natural resource management imperatives to generate win-win outcomes for biodiversity protection and native vegetation retention. However, the effectiveness of these tools will depend largely on how they are implemented "on the ground" (Bates 2006).

In Tasmania, the key drivers of land clearance have changed over time. In the late 1960 s to early 1970 s, a rise in commodity prices for fine wool became a driver for clearing to expand pasture, and for the use of woodlands and dry forest areas for grazing. In the 1970s and 1980s, significant clearance of native vegetation occurred for agricultural purposes. Clearing was undertaken largely in dry eucalypt forests in the east and northeast of the State. In the 1970s and 1980s conversion from broad-scale sheep and beef enterprises to more intensive dairy farming took place, involving some further clearing to expand existing pasture (AGO 2000).

Given that many important areas of Swift Parrot habitat occur on private property throughout the species' range, where voluntary conservation agreements are established (Tasmanian Government 2009; NSW Office of Environment and Heritage 2013, Tasmanian Government 2015) the habitat is given valuable protection in perpetuity that may not have otherwise occurred (Saunders \& Tzaros 2011). To complement these conservation initiatives, a long-term habitat protection and restoration project was recently funded by the NSW Environmental Trust. The project focuses on habitats within two priority regions of the species' winter range, and will commence on-ground works in 2017 across various tenure (NSW Office of Environment and Heritage 2016).

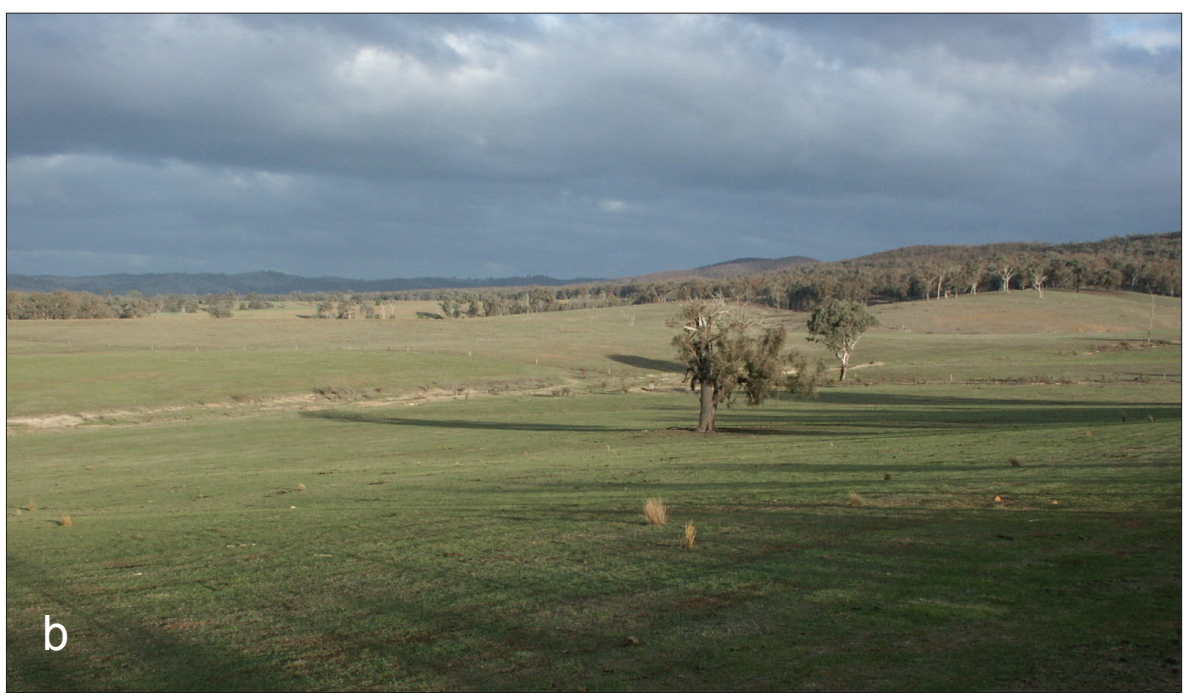

PLATE 11 - Remnant western slopes habitats. (a) Mates Gully Traveling Stock Reserve, near Tarcutta, New South Wales (2003) (Photo: Debbie Saunders, private collection). (b) Livingstone National Park, surrounded by agricultural land on the western slopes of New South Wales, was previously a state forest (2001) (Photo: Debbie Saunders, private collection). 


\section{URBAN, INDUSTRIAL AND MINING DEVELOPMENTS}

The spread of towns and cities to accommodate Australia's growing population continues to the present day with ongoing clearing of natural ecosystems (Commonwealth of Australia 2006b), including habitat for the Swift Parrot. With much of Australia's urban development undertaken prior to the 1980s (Commonwealth of Australia 2006b), and prior to the introduction and enforcement of environmental legislation (Frawley 1994), a legacy of extensive urban development surrounding fragmented and degraded natural environments remains (pl. 12). In the 1990s more comprehensive legislation for the environment and threatened species were introduced throughout the Swift Parrot range (e.g., NSW TSC Act, Victorian FFG Act and Commonwealth EPBC Act).

Environmental Impact Assessment processes for developments included detailed evaluation of the significance of impacts on threatened species and endangered ecological communities at both the state and federal levels (Chapple 2001, Department of Sustainability and Environment 2006a, Department of Environment and Water Resources 2007). However, after a number of years of EPBC Act implementation, the referral, assessment, approval and offsetting processes have failed to achieve the environmental objectives (Macintosh 2004, Macintosh \& Wilkinson 2005). This failure has often contributed to the "death by a thousand cuts" for biodiversity, in favour of economic development (Bates 2006). For example, the cumulative loss of Swift Parrot habitat continues to occur as a result of native vegetation clearing approvals for urban (Commonwealth of Australia 2002, 2007, NSW Government 2013), industrial (Saunders 2002, Commonwealth of Australia 2004, Group 2016) and mining developments (Australian Government 2004, 2011, 2013). As a result the decline of native species, including the Swift Parrot, and their habitats continues (Commonwealth of Australia 2009).

Biodiversity offsets are an increasingly popular yet controversial tool to deal with such losses in conservation. Their popularity lies in their potential to meet the objectives of biodiversity conservation and of economic development in tandem; the controversy lies in the need

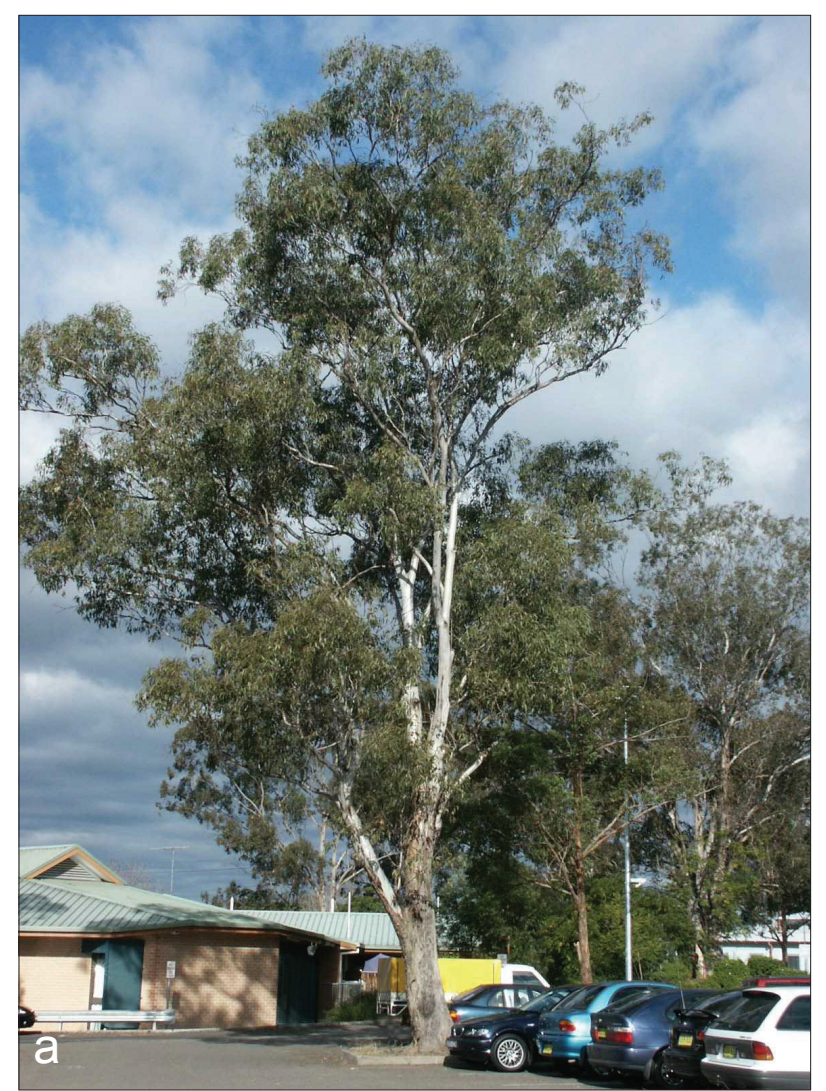

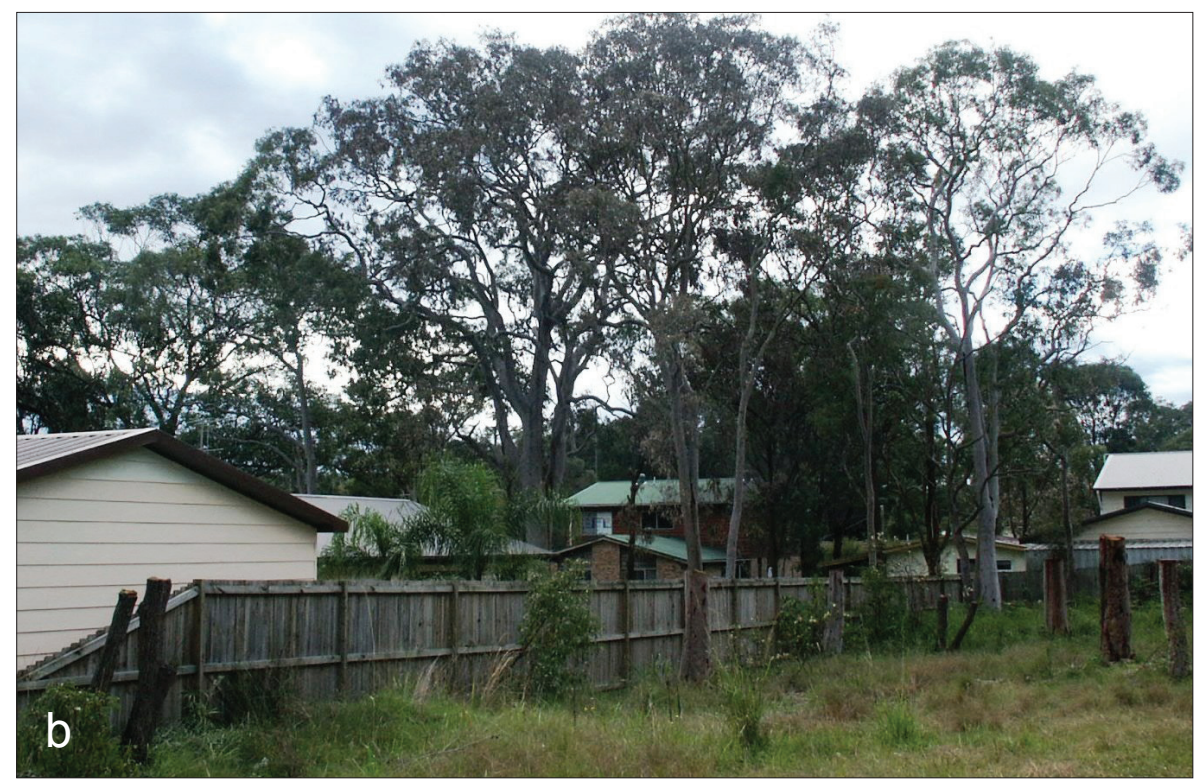

PLATE 12 - Remnants and individual trees in urban areas are often the only habitat that remains on the central coast of New South Wales. (a) Swift Parrot foraging habitat at Penrith, on the Cumberland Plain of western Sydney 2005. (Photo: Debbie Saunders, private collection). (b) Urban mass roosting site at Charmhaven, Central Coast NSW with evidence of incremental loss of remnant vegetation for further housing (Photo: Debbie Saunders, private collection). 
to accept ecological losses in return for uncertain gains. The offsetting approach is being widely adopted, even though its methodologies and the overriding conceptual framework are still under development (Bull et al. 2013). In NSW, BioBanking legislation was introduced in late 2006 with the aim of "no net loss" of biodiversity associated with development, particularly expanding urban and coastal development. However such biodiversity offset schemes have been found to be inconsistent in meeting conservation objectives because of the challenge of ensuring full compliance and effective monitoring and conceptual flaws in the approach itself (Burgin 2008, Bull et al. 2013). There is also a lack of supporting evidence for successful ecological restoration as a result of current offset policies (Maron et al. 2012).

The impacts of spreading urban development on the Swift Parrot have been most pronounced in coastal areas where $86 \%$ of Australia's human population now reside (Natural Resource Management Ministerial Council 2003). An example of such extensive habitat loss is illustrated by Forest Red Gum habitat on the central coast of NSW that only remains as individual trees scattered within an otherwise urban environment. Despite this, up to one third of the Swift Parrot population (650 birds, August 2002) have relied upon this urban habitat in some years, roosting and foraging in old trees in residential backyards (pers. obs.) (pl. 12). Furthermore, these impacts are likely to increase with growing pressure for extensive urban development along the southeastern coast of mainland Australia (winter habitat) and on the Tasmanian coastline (breeding habitat) (Commonwealth of Australia 2006b).

\section{CLIMATE CHANGE}

Anthropogenic climate change is another important conservation issue that has slowly gained recognition and support in policy, legislation and the broader community over the past twenty years (Allen Consulting Group 2005, Cowie 2007, Olsen 2007, IPCC 2014a). It has been established that climate change is affecting the phenology, physiology and distribution of numerous organisms, as well as the composition and dynamics of communities (Hughes 2000, Walther et al. 2002, Parmesan \& Yohe 2003, Parmesan 2006). Within the Australasian region, long-term trends demonstrate higher surface air and sea surface temperatures, more hot extremes and fewer cold extremes, as well as changed rainfall patterns. The uncertainty in projected rainfall creates significant challenges for adaptation and has the potential for severe implications for natural ecosystems (IPCC 2014b).

For migratory species, the effects of climate change may vary both spatially and temporally in different parts of the migratory cycle, making adaptation particularly complex and challenging (Moller et al. 2004). As a small migratory bird, the Swift Parrot has been identified as one of Australia's most vulnerable bird species to climate change impacts (Garnett et al. 2013). Habitat availability for Swift Parrots has long been predicted to significantly decrease in response to climate change within both their wintering (Bennett et al. 1991) and breeding areas (Brereton et al. 1995). As a cool climate nesting species, the Swift Parrot is highly intolerant of excessive heat, and nestlings can, and often do, die from heat exhaustion (Laubscher 1999, Pollard 2000). Therefore, conditions within currently suitable nesting habitat are predicted to become less optimal for successful breeding and fledging as global warming increases, with almost a quarter of current Swift Parrot nesting habitat projected to become climatically unsuitable by the end of the twentyfirst century (Porfirio et al. 2016). Further investigation of the full potential impact of climate change on the Swift Parrot and its habitat has been identified as a priority research area in the EPBC Act Conservation Advice (TSSC 2016) and the National Recovery Plan (Saunders \& Tzaros 2011).

As a nectarivore, the Swift Parrot is dependent on food sources directly influenced by climatic conditions such as rainfall and temperature (Law et al. 2000). With dry sclerophyll forests and woodlands predicted to experience increased temperatures over the next few decades (Dunlop and Brown 2008, Grose et al. 2010), this may lead to mismatches between the timing of migration and foraging habitat phenology within both breeding and non-breeding habitats. Such mismatches have been found to result in reduced fitness and survival in some migratory birds (Coppack et al. 2001, Coppack \& Both 2002, Bairlein \& Huppop 2004), although a diverse array of responses has been observed both in Australia and around the world (Lehikoinen et al. 2004, Gordo et al. 2005, Beaumont et al. 2006, Lehikoinen et al. 2006, Chambers 2008, Gordo \& Sanz 2008). The only study to examine the timing of Swift Parrot migration was conducted 10 years ago (Beaumont et al. 2006) and found no significant change in arrival date for the breeding grounds, however it is likely that the spatially variable nature of Swift Parrot habitat use (Webb et al. 2012) and/or the concentration of observers within one part of this breeding range, may have masked shifts in the timing of migration. Changed seasonality of rainfall may also increase the frequency and severity of bushfires resulting in the loss of key habitats such as Tasmanian Blue Gum, as well as increased levels of eucalypt dieback (DPIPWE 2010).

Swift Parrot habitat use is negatively correlated with large, aggressive species such as the Noisy Miner Manorina melanocephala (Latham 1802), and Rainbow Lorikeet Trichoglossus haematodus Linnaeus, 1771 (Saunders 2008), and ongoing habitat loss and fragmentation together with climate change are likely to result in greater abundance of such opportunistic and invasive species (Low 2008). Therefore the extensive physiological demands already on the species to locate a combination of distant and seasonally variable food sources from increasingly fragmented habitats (Saunders 2008), may be exacerbated by increased levels of negative inter-specific interactions in the future. Furthermore, when affected by a combination of such stressors, the immune system of migratory species may also become depressed to such an extent that their health, and ability to successfully migrate, is reduced (Bairlein 
\& Huppop 2004, Hoye et al. 2007). The health and sustainability of forests and woodlands currently inhabited by the Swift Parrot may also be impacted since this species plays an important role in pollination of the tree species in which it forages (Hingston et al. 2004).

Although climate change impacts on the Swift Parrot and its habitat are becoming increasingly evident, the type and extent of these impacts will depend on the cumulative impacts from all threats to the species (Opdam \& Wascher 2004, Pimm 2008, Felton et al. 2009) including habitat loss, predation, collisions with human made structures, competition, disease and illegal capture (Saunders \& Tzaros 2011).

\section{CONCLUSION}

The combination of images and other historical information on Swift Parrots and their habitat from colonial to recent times, provides valuable insights into the spatial and temporal extent of impacts on the species over more than 200 years. It illustrates how Swift Parrots depend on forests and woodlands that have been sought after, and extensively cleared and altered by humans since the late eighteenth century, and reveals the ongoing vulnerability of this species despite recognition of its conservation significance for over twenty years (Brown 1989, Brereton 1996, Marshall 2006, Saunders \& Tzaros 2011).

To ensure the conservation of Swift Parrots there is an urgent need to protect existing breeding and foraging habitat across a diversity of tenure in southeastern Australia; reduce the impact of Sugar Glider predation; better understand and manage all trophic levels of climate change impacts and to substantially increase habitat reestablishment throughout the species' range. Without strong direct action at all levels, from local landholders through to state and national government agencies responsible for managing this species and its habitat, the future of this species is far from secure.

\section{REFERENCES}

AGO 2000: Land clearing: a social history. Australian Greenhouse Office, Canberra.

Allchin, R., Kirkpatrick, J.B. \& Kriwoken, L. 2013: On not protecting the parrot - the impact of conservation and planning legislation on an endangered species in Tasmania. Journal of International Wildlife Law and Policy 16: 81-104.

Allen Consulting Group 2005: Climate Change Risk and Vulnerability. Promoting an efficient adaptation response in Australia. Australian Greenhouse Office, Department of the Environment and Heritage, Canberra.

Australian Government 2004: Environment Protection and Biodiversity Conservation Act 1999 Referral Decision EPBC 2003/974. To construct and operate the expansion of the Carshalton Mine Complex at Bendigo, Victoria. Decision to approve the taking of an action. Canberra.

Australian Government 2011: Rocglen Coal Mine Extension Project, near Gunnedah, New South Wales (EPBC 2010/5502). Australian Government, Canberra.

Australian Government 2013: Ravensworth Operations Project EPBC 2010/5389. Australian Government, Canberra.
Bairlein, F. \& Huppop, O. 2004: Migratory Fuelling and Global Climate Change. In Moller, A., Fiedler, W. \& Berthold, P (eds): Advances in Ecological Research. 35: 33-47. Academic Press, UK.

Bates, G. 2006: Environmental Law in Australia. LexisNexis Butterworths, Chatswood.

Batey, I. 1907: On fifteen thousand acres: its bird-life sixty years ago. The Emu 7: 1-17.

Beaumont, L.J., McAllan, I.A.W. \& Hughes, L. 2006: A matter of timing: changes in the first date of arrival and last date of departure of Australian migratory birds. Global Change Biology 12: 1339-1354.

Beeton, R., Buckley, K.I., Jones, G.J., Morgan, D., Reichelt, R.E. \& Trewin, D. 2006: Australia State of the Environment 2006. Department of the Environment and Heritage, Canberra.

Bennett, S., Brereton, R., Mansergh, I., Berwick, S., Sandiford, K. \& Wellington, C. 1991: The potential effect of enhanced greenhouse climate change on selected Victorian fauna. Department of Conservation and Environment, Melbourne.

Brereton, R. 1996: The Swift Parrot Recovery Plan 1997 - 1999. Tasmanian Parks and Wildlife Service, Hobart.

Brereton, R., Bennett, S., Mansergh, I. 1995: Enhanced greenhouse climate change and its potential effect on selected fauna of south-eastern Australia: a trend analysis. Biological Conservation 72: 339-354.

Brown, P.B. 1989: The Swift Parrot Lathamus discolor White: A report on its ecology, distribution and status, including management considerations. Technical Report. Department of Lands, Parks and Wildlife, Hobart.

Bull, J.W., Suttle, K.B., Gordon, A., Singh, N. \& MilnerGulland, E.J. 2013: Biodiversity offsets in theory and practice. Oryx 47: 369-380.

Burgin, S. 2008: BioBanking: an environmental scientist's view of the role of biodiversity banking offsets in conservation. Biodiversity and Conservation 17: 807-816.

Carron, L.T. 1985: A History of Forestry in Australia. Australian National University Press, Canberra: 355 pp.

Chambers, L.E. 2008: Trends in timing of migration of southwestern Australian birds and their relationship to climate. EMU 108: 1-14.

Chapman, T.E. 1835-1860. At Derwent Park, New Town V.D.L. Allport Library and Museum of Fine Arts, ADRI: AUTAS001124061300 State Library of Tasmania, Hobart). Watercolour painting on paper.

Chapple, S. 2001: The EPBC Act: one year later. Environmental Planning and Law Journal (EPLJ) 18: 523-539.

COAG Standing Council on Environment and Water 2012: Australia's Native Vegetation Framework. Canberra.

Commonwealth of Australia 1983: A National Conservation Strategy for Australia: Living resource conservation for sustainable development. Australian Government Publishing Service, Canberra.

Commonwealth of Australia 1992: National Forest Policy Statement. Commonwealth of Australia, Canberra.

Commonwealth of Australia 2000: Commonwealth Listing Advice on Cumberland Plain Woodlands. EPBC Act List of Threatened Ecological Communities. Commonwealth of Australia, Canberra.

Commonwealth of Australia 2002: Environment Protection and Biodiversity Conservation Act 1999 Referral Decision EPBC 2002/711. Mirvac Homes subdivision, The Entrance $\mathrm{Rd}$, Bateau Bay. Decision that action is not a controlled action. Commonwealth of Australia, Canberra.

Commonwealth of Australia 2004: Environment Protection and Biodiversity Conservation Act 1999 Referral decision EPBC 2004/1417. To develop the Hunter Economic Zone Industrial Estate, Hunter Valley, New South Wales. Decision to approve the taking of an action. Commonwealth of Australia, Canberra. 
Commonwealth of Australia 2006a: Australian Historical Population Statistics. Population by sex, state and territories. 31 December, 1788 onwards. Cat. no. 3105.0.65.001. Commonwealth of Australia, Canberra.

Commonwealth of Australia 2006b: Australian State of the Environment 2006. Commonwealth of Australia, Canberra.

Commonwealth of Australia 2007: Environment Protection and Biodiversity Conservation Act 1999 Referral Decision EPBC 2007/3880. Avery Village Partnership/Residential development/Avery's Lane, Heddon Greta, Cessnock, 2 $\mathrm{km} \mathrm{NE}$ of Kurri Kurri/NSW/Rezoning and Residential Development of Avery's Village, Cessnock, NSW. Decision approval not required - particular matter. Commonwealth of Australia, Canberra.

Commonwealth of Australia 2008: Regional Forest Agreements. Commonwealth of Australia, Canberra.

Commonwealth of Australia 2009: The operation of the Environment Protection and Biodiversity Conservation Act 1999. Second and final report from the Inquiry into the operation of the Environment Protection and Biodiversity Conservation Act 1999. Commonwealth of Australia, Canberra.

Coppack, T. \& Both, C. 2002: Predicting life-cycle adaptation of migratory birds to global climate change. Ardea 90: 369-378.

Coppack, T., Pulido, F. \& Berthold, P. 2001: Photoperiodic response to early hatching in a migratory bird species. Oecologia 128: 181-186.

Cowie, J. 2007: Climate Change: Biological and Human Aspects. Cambridge University Press, Cambridge: 504 pp.

Cubit, S. 1996: Recollections from the Forest. 75 years of Forest Service in Tasmania. Forestry Tasmania, Hobart: 247 pp.

Datta, A. 1997: John Gould in Australia:letters and drawings with a catalogue of manuscripts, correspondence and drawings relating to the birds and mammals of Australia held in The Natural History Museum, London. Melbourne University Press and The Miegunyah Press, Carlton South.

DECCW 2009: Planning for catchment biodiversity targets at a local landscape scale: a proposal for the South-west Slopes Bioregion of NSW. NSW Government, Sydney.

Department of Environment and Water Resources 2007: EPBC Act - Environment Assessment Process. Australian Government, Canberra.

Department of Natural Resources 2006: Compliance under the Native Vegetation Act 2003. NSW Government, Sydney.

Department of Natural Resources and Environment 2002a: Government response to Environment Conservation Council Box-Ironbark Forests and Woodlands Investigation. Victorian Government, Melbourne.

Department of Natural Resources and Environment 2002b: Victoria’s Native Vegetation Management - a Framework for Action. Victorian Government, Melbourne.

Department of Primary Industries Water and Environment 2000: Threatened Species Strategy for Tasmania. Tasmanian Government, Hobart.

Department of Sustainability and Environment 2003: Habitat Tree Prescriptions for Bendigo Forest Management Area. Victorian Government, Bendigo.

Department of Sustainability and Environment 2006a: Ministerial guidelines for assessment of environmental effects under the Environment Effects Act 1978. Victorian Government, Melbourne.

Department of Sustainability and Environment 2006b: Native Vegetation - sustaining a living landscape. Victorian Government, Melbourne.

DPIPWE 2010: Vulnerability of Tasmania's Natural Environment to Climate Change: An Overview. Unpublished report. Department of Primary Industries, Parks, Water and Environment, Hobart.

Dunlop, M. \& Brown, P.R. 2008: Implications of climate change for Australia's National Reserve System: A preliminary assessment. Report to the Department of Climate Change, February 2008. Canberra.

Dymock, W. 1870-1899: A new plan of the settlements in New South Wales: taken by order of Government. William Dymock, Sydney. National Library of Australia, Map 377 from Ferguson Collection Bib ID: 1853368, Canberra. Reprint. Originally published by John Booth 1810.

Ecologically Sustainable Development Steering Committee 1992: National Sustainable Development Strategy. Commonwealth of Australia, Canberra. http://www. environment.gov.au/about-us/esd/publications/nationalesd-strategy.

EDO 2015: Review of the Forest Practices Code 2000. Environmental Defenders Office, Hobart. http://www. edotas.org.au/wp-content/uploads/2013/10/150515Review-of-Forest-Practices-Code-EDO-Tasmaniasubmission.pdf.

EDO 2016: Our top 10 concerns with the draft Biodiversity Conservation Bill 2016 and Local Land Services Amendment Bill. http://www.edonsw.org.au/edo_nsw_ top_10_concerns_with_draft_biodiversity_conservation bill_2016_and_local_land_services_amendment_bill [Accessed 9 November 2015].

Environment Conservation Council 2001: Box-Ironbark Forests and Woodlands Investigation. Environment Conservation Council, Melbourne.

Environment Protection Authority 2007: Nature Assist - nature refuges incentives and assistance. http://www.ehp.qld. gov.au/ecosystems/nature-refuges/natureassist/ [Accessed 15 June 2016].

Felton, A., Fischer, J., Lindenmayer, D.B., Montague-Drake, R., Lowe, A.R., Saunders, D.L., Felton, A.M., Steffen, W., Munro, N.T., Youngentob, K., Gillen, J., Gibbons, P., Bruzgul, J.E., Fazey, I., Bond, S.J., Elliott, C.P., Macdonald, B.C.T., Porfirio, L.L., Westgate, M. \& Worthy, M. 2009: Climate change, conservation and management: an assessment of the peer-reviewed scientific journal literature. Biodiversity and Conservation 18: 2243-2253.

Flinn, J. 2006: Which way now? Glen Waverley, Victoria. Source: Debbie Saunders, private collection. Watercolour painting.

Forest Practices Authority 2015: Forest Practices Code. Forest Practices Authority, Hobart.

Forest Practices Board 2000: Forest Practices Board Annual Report 1999-00. Hobart.

Forest Practices Board 2001: Forest Practices Board Annual Report 2000-01. Hobart.

Forest Practices Board 2002: Forest Practices Board Annual Report 2001-02. Hobart.

Frawley, K. 1994: Evolving visions: environmental management and nature conservation in Australia. In Dovers, S (ed.): Australian Environmental History. Oxford University Press, Melbourne: 55-78.

Garnett, S., Franklin, D., Ehmke, G., VanDerWal, J., Hodgson, L., Pavey, C., Reside, A., Welbergen, J., Butchart, S., Perkins, G. \& Williams, S. 2013: Climate change adaptation strategies for Australian birds. National Climate Change Adaptation Research Facility, Gold Coast: 925 pp.

Gibbons, P. \& Boak, M. 2002: The value of paddock trees for regional conservation in an agricultural landscape. Ecological Management and Restoration 3: 205-210.

Gill, S.T. 1855: Diggings at Little Bendigo, Forest Creek, 1852. James J. Blundell \& Co., Melbourne. Source: National Library of Australia, Bib ID 438003, Canberra. Lithograph print. A plate from: The diggers \& diggings of Victoria as they were in 1852 . Pt. 1. S4014.

Gill, S.T. 1874: Diggings in the Mount Alexander district of Victoria in 1852. Source: National Library of Australia, Bib ID 3112373, Canberra. Watercolour painting on paper.

Google 2015: GoogleEarth with images from NASA DigitalGlobe 
and TerraMetrics.

Gordo, O., Brotons, L., Ferrer, X. \& Comas, P. 2005: Do changes in climate patterns in wintering areas affect the timing of the spring arrival of trans-Saharan migrant birds? Global Change Biology 11: 12-21.

Gordo, O. \& Sanz, J.J. 2008: The relative importance of conditions in wintering and passage areas on spring arrival dates: the case of long-distance Iberian migrants. Journal of Ornithology 149: 199-210.

Gould, J. 1848: Lathamus discolor in Eucalyptus gibbosus. Birds of Australia and Adjacent Islands (Volume V). John Gould, London: pp. 101-103, Plate 47. (Source: National Library of Australia, Canberra)

Gould, J., Geoffroy Saint-Hilaire, E. \& Mathews, G.M. :1848: The Birds of Australia: and the Adjacent Islands. (The author, London)

Gould, W.B. 1840s: Birds. Source: Art Gallery of Ballarat, Gift of $\mathrm{Mr}$ and Mrs Wallace White, 1980, Ballarat.

Gramenz, E. 2016: Critically endangered swift parrot breeding ground in Tasmania illegally logged for firewood. ABC News, 30 July 2016 http://www.abc.net.au/ news/2016-07-29/swift-parrot-habitat-illegaly-logged-forfirewood/7672504? section=tas

Grant, T.C. 1989: History of foresty in New South Wales 1788 to 1988. Star Printery, Erskinville.

Grinlinton, D. 1990: The Environmental Era and the Emergence of Environmental Law in Australia - a survey of Environmental Legislation and Litigation 1967-1987. Environmental Planning and Law Journal (EPLJ) 7: 74.

Grose, M., Barnes-Keoghan, I., Corney, S., White, C., Holz, G., Bennett, J., Gaynor, S. \& Bindoff, N. 2010: Climate Futures for Tasmania: general climate technical report. Antarctic Climate and Ecosystems Cooperative Research Centre, Hobart.

Group, S.H. 2016: Generations Industrial Park EPBC Act Referral. Saunders Havill Group, Bowen Hills. http://epbcnotices. environment.gov.au/_entity/annotation/59d75e65-dc4fe611-98e5-005056ba00a7/a71d58ad-4cba-48b6-8dab$\mathrm{f} 3091 \mathrm{fc} 31 \mathrm{~cd} 5$ ? $\mathrm{t}=1469681537978$.

Halliday, K. 2005: Community Based Shire Wide Heritage Study Documents 2004-05. Liverpool Plains Shire Heritage Community Advisory Committee. Liverpool Plains Shire Council and NSW Heritage Office, Quirindi.

Heinsohn, R., Webb, M., Lacy, R., Terauds, A., Alderman, R. \& Stojanovic, D. 2015: A severe predator-induced population decline predicted for endangered, migratory swift parrots (Lathamus discolor). Biological Conservation 186: $75-82$.

Hindwood, K.A. \& Sharland, M. 1964: The swift parrot. EMU 63: 310-326.

Hingston, A.B., Potts, B.M. \& McQuillan, P.B. 2004: The swift parrot Lathamus discolor (Psittacidae), social bees (Apidae), and native insects as pollinators of Eucalyptus globulus ssp. globulus (Myrtaceae). Australian Journal of Botany 52: 371-379.

Hoye, B., Klaassen, M. \& Nolet, B.A. 2007: Ecophysiology of bird migration in the face of current global hazards: Climate change and avian flu. Comparative Biochemistry and Physiology a-Molecular \& Integrative Physiology 148: S128-S128.

Hughes, L. 2000: Biological consequences of global warming: is the signal already apparent? Trends in Ecology \& Evolution 15: $56-61$.

Ingwersen, D. \& Tzaros, C. 2011: Woodland Birds. Wingspan Winter: 22-25.

Innes, E.G. 1896: Reports of District Surveyors. Survey District of Franklin. In: 1896, Session II. Parliament of Tasmania, Department of Lands and Surveys: Report of SurveyorGeneral and Secretary for Lands for 1895. Parliamentary Paper No. 47. Appendix B. Government Printer, Hobart: $15-16$.
IPCC 2014a: Climate Change 2014: Impacts, Adaptation and Vulnerability. Summary for Policymakers. Intergovernmental Panel on Climate Change No. Working Group II Contribution to the Intergovernmental Panel on Climate Change (IPCC) Fifth Assessment Report, Geneva.

IPCC 2014b: Regional Chapter 25, Australasia. In Climate Change 2014: Impacts, Adaptation and Vulnerability. (Intergovernmental Panel on Climate Change, Geneva)

IUCN 2015: IUCN Red List of Threatened Species. Version 2013.2. www.iucnredlist.org [Accessed 26 May 2016].

IUCN, UNEP, WWF 1980: World Conservation Strategy. Living resource conservation for sustainable development. International Union for the Conservation of Nature, Gland Switzerland.

Juniper, T. \& Parr, M. 1998: Parrots - A Guide to Parrots of the World. Pica Press, Sussex.

Kennedy, S.J. \& Overs, A.E. 2001: Foraging ecology and habitat use of the swift parrot on the south-western slopes of New South Wales. Corella 25: 68-74.

Kirkpatrick, J.B. 1991: The magnitude and significance of land clearance in Tasmania in the 1980's. Tasforests December: $11-14$.

Kirkpatrick, J.B.\& Dickinson, K.J. 1982: Recent destruction of natural vegetation in Tasmania. Search 13: 186-187.

Kirkpatrick, J.B. \& Mendel, L. 1999: Native Vegetation Loss in Tasmania 1994-99. Unpublished report. University of Tasmania, Hobart.

Kuussaari, M., Bommarco, R., Heikkinen, R.K., Helm, A., Krauss, J., Lindborg, R., Öckinger, E., Pärtel, M., Pino, J., Rodà, F., Stefanescu, C., Teder, T., Zobel, M. \& Steffan-Dewenter, I. 2009: Extinction debt: a challenge for biodiversity conservation. Trends in Ecology \& Evolution 24: 564-571.

Laubscher, C. 1999: The Swift Parakeet. The Parrot Society UK Special Edition. Principal Colour Ltd, U.K.

Law, B., Mackowski, C., Schoer, L. \& Tweedie, T. 2000: Flowering phenology of myrtaceous trees and their relation to climatic, environmental and disturbance variables in northern New South Wales. Austral Ecology 25: 160-178.

Lehikoinen, A., Kilpi, M. \& Ost, M. 2006: Winter climate affects subsequent breeding success of common eiders. Global Change Biology 12: 1355-1365.

Lehikoinen, E.S.A., Sparks, T.H., Zalakevicius, M.A. \& Moller, W.Fa.P.B. 2004: Arrival and Departure Dates. Advances in Ecological Research 35: 1-31. Academic Press, UK.

Low, T. 2008: Warming, invasive pests and birds. In Olsen, P. (ed.): The State of Australia's Birds 2007. Birds in a changing climate. Birds Australia, Melbourne: 18-19

Lunt, I.D. \& Spooner, P.G. 2005: Using historical ecology to understand patterns of biodiversity in fragmented agricultural landscapes. Journal of Biogeography 32: 1859-1873.

Macintosh, A. 2004: Why the Environment Protection and Biodiversity Conservation Act's referral, assessment and approval process is failing to achieve its environmental objectives. Environmental Planning and Law Journal (EPLJ) 21: 288-311.

Macintosh, A. \& Wilkinson, D. 2005: Environment Protection and Biodiversity Conservation Act: A five year assessment. Discussion Paper 81. The Australia Institute, Canberra.

Maron, M., Hobbs, R.J., Moilanen, A., Matthews, J.W., Christie, K., Gardner, T.A., Keith, D.A., Lindenmayer, D.B. \& McAlpine, C.A. 2012: Faustian bargains? Restoration realities in the context of biodiversity offset policies. Biological Conservation 155: 141-148.

Marshall, J. 2006: Brown v Forestry Tasmania Summary (No 4) FCA 1729, 19 December 2006. Federal Court of Australia, Hobart.[Accessed 14 August 2007].

Ministerial Review Committee 2006: Consolidated Report to the Ministers for Natural Resources and the Environment. NSW Native Vegetation Reforms. Ministerial Review 
Committee, Canberra.

Moller, A.P., Berthold, P. \& Fiedler, W. 2004: The challenge of future research on climate change and avian biology. Advances in Ecological Research 35: 237-245. Academic Press, UK.

Munks, S., Richards, K., Meggs, J. \& Brereton, R. 2004: The importance of adaptive management in 'off-reserve' conservation for forest fauna: implementing, monitoring and upgrading swift parrot Lathamus discolor conservation measures in Tasmania. In In Lunney, D. (ed.): Conservation of Australia's Forest Fauna. Royal Zoological Society, Mosman: 688-698.

Munro Hull, H. 1859: Hobart Town, from the tower of St. David's Church. Black and white picture. In Experience of Forty Years in Tasmania. Orger \& Meryon, London and J. Walch and Sons, Hobart: 87. ADRI: AUTAS001126075480, State Library of Tasmania, Hobart.

Natural Resource Management Ministerial Council 2000: National Framework for the Management and Monitoring of Australia's Vegetation. Australian Government, Canberra.

Natural Resource Management Ministerial Council 2003: Framework for a national cooperative approach to Integrated Coastal Zone Management. Natural Resource Management Ministerial Council, Canberra.

Natural Resources and Water 2007: Vegetation management framework - fact sheet. The State of Queensland, Brisbane.

North, A.J. 1898: Birds of the County of Cumberland. Handbook of the Australian Association for the Advancement of Science 68-116.

NSW Department of Primary Industries 1999: Integrated Forest Operations Approval for Upper North East, Lower North East and Eden regions. Forestry and National Park Estate Act 1998. NSW Government, Sydney.

NSW Government 2013: Pacific Highway upgrade, Woolgoolga to Ballina. Biodiversity offset strategy, Swift Parrot. NSW Government, Sydney.

NSW Government 2014: Crown Lands Management Review. Chapter 4: Review of travelling stock reserves. NSW Government, Sydney.

NSW Local Land Services 2015: NSW Travelling Stock Reserves. Draft State Planning Framework 2016-19. NSW Government, Sydney.

NSW Office of Environment and Heritage 2013: Conservation agreements. http://www.environment.nsw.gov.au/cpp/ ConservationAgreements.htm [Accessed 15 June 2016].

NSW Office of Environment and Heritage 2016: Saving Our Species partnerships grants - Round 2 project summaries. Australian National University. Saving our Swift Parrots and threatened woodland species. http://www.environment. nsw.gov.au/grants/2016-sos-summary.htm [Accessed 9 November 2015].

NSW Scientific Committee 1997: Cumberland Plain Woodland - endangered ecological community listing. http:// www.nationalparks.nsw.gov.au/npws.nsf/Content/ Final+determinations [Accessed 30 January 2016].

NSW Scientific Committee 2001: Native vegetation on cracking clay soils of the Liverpool Plains - endangered ecological community listing. http://www.nationalparks.nsw.gov. au/npws.nsf/Content/Final+determinations [Accessed 8 September 2015].

NSW Scientific Committee 2002: White Box, Yellow Box, Blakely's Red Gum Woodland - endangered ecological community listing. http://www.nationalparks.nsw.gov. au/npws.nsf/Content/Final+determinations [Accessed 30 January 2015].

NSW Scientific Committee 2004a: River-flat eucalypt forest on coastal floodplains of the NSW North Coast, Sydney Basin and South East Corner Bioregions - endangered ecological community listing. http://www.nationalparks.nsw.gov. $\mathrm{au} / \mathrm{npws}$.nsf/Content/Final+determinations [Accessed 30 January 2015].
NSW Scientific Committee 2004b: Swamp sclerophyll forest of the NSW North Coast, Sydney Basin and South East Corner Bioregions - endangered ecological community listing. http://www.nationalparks.nsw.gov.au/npws.nsf/Content/ Final+determinations [Accessed 30 January 2015].

NSW Scientific Committee 2005: Lower Hunter Spotted Gum Ironbark Forest in the Sydney Basin Bioregion - endangered ecological community listing. http://www.nationalparks. nsw.gov.au/npws.nsf/Content/Final+determinations [Accessed 30 January 2015].

NSW Scientific Committee 2006: Inland Grey Box Woodland in the Riverina, New South Western Slopes, Cobar Peneplain, Nandewar and Brigalow Belt South Bioregions - endangered ecological community preliminary listing. http://www.nationalparks.nsw.gov.au/npws.nsf/Content/ Final+determinations [Accessed 9 November 2015].

O'Connor, T. 2016: Swift Parrot egg safe havens a 'bonanza' for endangered species. 7 October 2016. ABC News http:// www.abc.net.au/news/2016-10-07/swift-parrot-eggsfound-in-experimental-nesting-boxes/7911138 [Accessed 9 November 2016].

Olsen, P. (ed.) 2007: The State of Australia's Birds 2007. Birds in a changing climate. Birds Australia, Melbourne.

Opdam, P. \& Wascher, D. 2004: Climate change meets habitat fragmentation: linking landscape and biogeographical scale levels in research and conservation. Biological Conservation 117: 285-297.

PAHSMA 2007: Port Arthur Historic Site. http://www.portarthur. org.au/index.aspx?id=12731 [Accessed 4 September 2015].

Parmesan, C. 2006: Ecological and evolutionary responses to recent climate change. Annual Review of Ecology, Evolution, and Systematics 37: 637-669.

Parmesan, C. \& Yohe, G. 2003: A globally coherent fingerprint of climate change impacts across natural systems. Nature 421: 37-42.

Pimm, S.L. 2008: Biodiversity: Climate change or habitat loss - which will kill more species. Current Biology 18: R117-R119.

Pollard, M 2000: Keeping swift parrots. http://www.finchsociety. org/cfa/parrot/swift/swift.htm [Accessed 18 July 2015].

Porfirio, L.L., Harris, R.M.B., Stojanovic, D., Webb, M.H. \& Mackey, B. 2016: Projected direct and indirect effects of climate change on the Swift Parrot, an endangered migratory species. EMU 116: 273-283.

Powell, J.M. 1969: The squatting occupation of Victoria, 1834-60. Australian Geographical Studies 7: 9-27.

Pullinger, P. 2015: Pulling a swiftie. Systemic Tasmanian Government approval of logging known to damage swift parrot habitat. A report prepared for Environment Tasmania, Hobart.

Raper, G. c.1789: [Swift Parrot Lathamus discolor]. Attributed to George Raper (1769-1797). Source: National Treasures Collection of First Fleet Art, National Library of Australia, Canberra.

Resource Assessment Commission 1990: Australia's Forest and Timber Resources. Background paper No. 1. Resource Assessment Commission, Canberra.

Resource Planning and Development Commission 2003: State of the Environment Tasmania. Land Clearance Biodiversity Issues. Resource Planning and Development Commission (RPDC), Hobart. http://soer.justice.tas.gov.au/2003/ bio/4/issue/41/ataglance.php.

Ribbentrop, B. 1896: Report on the state forests of Victoria. Government Printer, Melbourne.

Saunders, D.L. 2002: Assessment of swift parrot sites near Cessnock, lower hunter valley region, N.S.W. - including the Hunter Employment Zone. Independant unpublished report for the N.S.W. National Parks and Wildlife Service, Queanbeyan.

Saunders, D.L. 2008: Ecology and conservation of the swift parrot - an endangered austral migrant. Unpublished 
PhD thesis, Australian National University.

Saunders, D.L. 2010: Review of NSW Forest Agreements and Integrated Forestry Operations Approvals. A submission to the NSW Department of Environment Climate Change and Water. Australian National University, Canberra.

Saunders, D.L., Brereton, R., Tzaros, C., Holdsworth, M. \& Price, R. 2007: Conservation of the swift parrot Lathamus discolor-management lessons for a threatened migratory species. Pacific Conservation Biology 13: 111-119.

Saunders, D.L., Cunningham, R., Wood, J. \& Heinsohn, R. 2016: Responses of Critically Endangered migratory swift parrots to variable winter drought. EMU http://dx.doi. org/10.1071/MU15126, -.

Saunders, D.L. \& Heinsohn, R. 2008: Winter habitat use by the endangered, migratory swift parrot (Lathamus discolor) in New South Wales, Australia. EMU 108: 81-89.

Saunders, D.L. \& Tzaros, C. 2011: National recovery plan for the swift parrot Lathamus discolor. Birds Australia, Melbourne.

State of NSW 2014: A review of biodiversity legislation in NSW. Final Report. Office of Environment and Heritage, Sydney. http://www.environment.nsw.gov.au/resources/ biodiversity/BiodivLawReview.pdf.

Stojanovic, D., Terauds, A., Westgate, M.J., Webb, M.H., Roshier, D.A. \& Heinsohn, R. 2015: Exploiting the richest patch has a fitness pay-off for the migratory swift parrot. Journal of Animal Ecology 84: 1194-1201.

Stojanovic, D., Webb, M., Roshier, D., Saunders, D. \& Heinsohn, R. 2012: Ground-based survey methods both overestimate and underestimate the abundance of suitable tree-cavities for the endangered swift parrot. EMU 112: 350-356.

Stojanovic, D., Webb, M.H., Alderman, R., Porfirio, L.L. \& Heinsohn, R. 2014: Discovery of a novel predator reveals extreme but highly variable mortality for an endangered migratory bird. Diversity and Distributions 20: 1200-1207.

Tasmanian Government 2005: Tasmanian Community Forest Agreement. Commonwealth of Australia, Canberra.

Tasmanian Government 2009: Tasmanian Forest Conservation Fund. Commonwealth of Australia, Canberra.

Tasmanian Government 2015: Protected Areas on Private Land (PAPL). http://dpipwe.tas.gov.au/conservation/ conservation-on-private-land/private-land-conservationprogram/protected-areas-on-private-land [Accessed 15 June 2016].

Tasmanian Government 2016: Policy for maintaining a Permanent Native Forest Estate. Tasmanian Government, Hobart.

Tasmanian Lands Department 1917: Port Arthur 1844 F.P. Tasmanian Lands Department, Hobart. Source: Allport Library and Museum of Fine Arts and State Library of Tasmania, ADRI:AUTAS001124072174, Hobart. Print, photocopy on linen.
TSSC 2016: Conservation Advice Swift Parrot Lathamus discolor, established under the Environment Protection and Biodiversity Conservation Act 1999. Australian Government, Canberra, ACT.

Turner, J.W. 1996: Thematic history of Eurobodalla Shire. Hunter History Consultants, Newcastle. http://www.esc.nsw.gov. au/living-in/about/culture-and-heritage/heritage-studies/ ThematicHistoryEShire.pdf.

Unknown Photographer 1877-: Bullock teams dragging logs to mill. Mill erected 1877. Cut timbers for local use including original Tarraganda Bridge. View looking west - Tanja via Bega, NSW. Mitchell Library, State Library of NSW, Sydney. Photograph, call number: At Work and Play - 02065.

Unknown Photographer 1880-1940: $7 \mathrm{ft}$ high wheat crop on "Kia Ora", Grogan - Grogan, Temora area, NSW. Mitchell Library, State Library of NSW, Sydney. Photograph, call number: At Work and Play - 02881.

Victoria Parliament 1865: Report on the avisableness of establishing state forests. Parliamentary paper 77 . The votes and proceedings of the legislative assembly 1864-5. Government Printer, Melbourne.

Victoria Parliament 1874: Papers relating to forest conservancy. Parliamentary paper 86 . Legislative assembly papers presented to parliament. Government Printer, Melbourne.

Voogdt, J. 2006: Characteristics of swift parrot (Lathamus discolor) nesting habitat. Unpublished Honours thesis, GerofAugust-University of Gottingen.

Wadham, S. 1967: Australian Farming 1788-1965. F.W. Cheshire, Melbourne.

Walther, G.R., Post, E., Convey, P., Menzel, A., Parmesan, C., Beebee, T.J.C., Fromentin, J.M., Hoegh-Guldberg, O. \& Bairlein, F. 2002: Ecological responses to recent climate change. Nature 416: 389-395.

Watling, T. 1793-1795: North-West View taken from the Rocks above Sydney Cove in New South Wales. Source: Natural History Museum, London. Watling Drawing no. 131.

Webb, M.H., Holdsworth, M.C. \& Webb, J. 2012: Nesting requirements of the endangered swift parrot (Lathamus discolor). EMU 112: 181-188.

Webb, M.H., Wotherspoon, S., Stojanovic, D., Heinsohn, R., Cunningham, R., Bell, P. \& Terauds, A. 2014: Location matters: Using spatially explicit occupancy models to predict the distribution of the highly mobile, endangered swift parrot. Biological Conservation 176: 99-108.

(accepted 6 December 2016) 
